Winter 12-2000

\title{
Between Hölderlin and Heidegger: Nietzsche's Transfiguration of Philosophy
}

Babette Babich

Fordham University, babich@fordham.edu

Follow this and additional works at: https://fordham.bepress.com/phil_babich

Part of the Continental Philosophy Commons, German Language and Literature Commons, and the History of Philosophy Commons

\section{Recommended Citation}

Babich, Babette, "Between Hölderlin and Heidegger: Nietzsche's Transfiguration of Philosophy" (2000). Articles and Chapters in Academic Book Collections. 33.

https://fordham.bepress.com/phil_babich/33 


\section{BETWEEN HÖLDERLIN AND HEIDEGGER: NIETZSCHE'S TRANSFIGURATION OF PHII.OSOPHY}

Among Nietzsche's many offerings for philosophy, he proposes the following physiological imperative for thought: "Unser Denken soll kräftig duften wie ein Kornfeld an Sommer-Abenden." (Nachlaß 1878, KSA 8, 30[126]) ${ }^{1}$ That our thinking does not have this fragrance of abundant expression or growth is not the only reason Nietzsche's sentimental proclamation seems more poetic than philosophical. Heidegger suggests Nietzsche's deeper melancholy when he asks in Nietzsche's name and almost in Nietzsche's voice, "Wie viele haben heute noch die Sinne für diesen Duft?"2 On the standards of contemporary philosophy - even recalling Nietzsche's trademark attention to the other bodily senses of the five reduced by philosophy since Plato to nothing but sightless (or ideal) vision - talk of the ideal "fragrance" of thought offers a metaphoricity beyond the pale of philosophic reason. Nietzsche speaks as he does for the sake of just that subtlety, calling for a transfiguration of philosophy, a finesse beyond even his own dreams for a thinker or a friend, for a philosopher with exceeding fine fingers, possessing "jene Filigran-Kunst des Greifens und Begreifens überhaupt". 3

Nietzsche's "feast" of abstract thought, ${ }^{4}$ like Heidegger's celebration of thinking, like Hölderlin's consummate Feiertag, or marriage of gods and mortal beings - as on that a-orgic day of abundant song - promises a transfigured philosophy which would not only strive for a wisdom beyond prejudice (beyond the "Vorurtheile" of Nietzsche's reading of the history of philosophy, JGB 1), but would attend to the complexity of style: what is written between the lines,

1 Cited by Heidegger, Martin: Das Wesen der Sprache. Unterwegs zur Sprache. 10. Aufl. Pfullingen 1993, pp. 173-174.

Heidegger: Das Wesen der Sprache, op. cit., p. 174. Cf. Za IV, Das Nachtwandler-Lied 6, KSA 4 , p. 400 .

"Selbst jene Filigran-Kunst des Greifens und Begreifens überhaupt, jene Finger für nuances, jene Psychologie des 'Um-die-Ecke-sehns' und was sonst mir eignet." (FH, Warum ich so weise bin 1)

+ "Das abstrakte Denken ist für Viele eine Mühsal, - für mich, an guten Tagen, ein Fest und cin Rausch" (Nachlaß 1885, KSA 11, 34|130|). Heidegger cites this phrase from Nietzsche's Nacblaß (in: Nietzsche I. Pfullingen 1961, p. 14), to prove, almost contra Nietzsche's challenge in JGB 16, that Nietzsche was not only a philosopher but one who knew what thinking is. 
spoken, as Heidegger has expressed it, in what is unsaid, and which does not use the rule or judgment of madness to anticipate the spirit or the end of a philosophy or a poetry in advance.

Such a transfiguration would require that the ordinal form of philosophic discourse - logical demonstration and analytic clarification - be broadened to include the elements of style, not only for the sake of the clear and distinct representation of ideas, but, much more importantly, to say what cannot be said in ordinary philosophy books in ordinary philosophical language but which Nietzsche does say aphoristically. This style corresponds to his philosophic standard for precision and provocation: "Der Aphorismus, die Sentenz, in denen ich als der Erste unter Deutschen Meister bin, sind die Formen der ,Ewigkeit”; mein Ehrgeiz ist, in zehn Sätzen zu sagen, was jeder Andre in einem Buche sagt, - was jeder Andre in einem Buche nicht sagt ..." (GD, KSA 6, p. 153). In the polemic, as in the aphorism, beyond the limitations of logical argument, Nietzsche leaves the greater part of philosophy (as the task of philosophic reading and thinking) to the reader, exceeding the mechanisms for preserving the truth we already possess (i. e., the tools of rational argument), to ask both if we have the truth to begin with and whether we want it in any case, in the end: "Wer ist das eigentlich, der uns hier Fragen stellt? Was in uns will eigentlich „zur Wahrheit”?” (JGB 1, KSA 5, p. 15). Such a style of philosophic provocation, as the very question of "style," hardly converts philosophy to poetry but it does draw on the resources of the poetic word.

Nietzsche's transfiguration of philosophy speculates on the draft of reason, testing the motivating directions of its truth, as the adversary of "Die „Vernunft" in der Philosophie." (GD, KSA 6, p. 74) But if philosophy is invited to think beyond reason, thinking's own self-nominated advocate at the end of philosophy declares that beyond the traditional project of philosophic understanding, "Das Denken ist kein Mittel für das Erkennen. Das Denken zieht Furchen in den Acker des Seins." These are "unscheinbare Furchen" traced in language, as spoken by the thinker with Hölderlin's word in his mouth ${ }^{6}$ and thus invoking the proximity (or the interdependence) of poetry and thought:?

Es brauchet aber Stiche der Fels

Ind Furchen die Eird',

Unwirthbar wär es, obne Weile.

5 Heidegger: Das Wesen der Sprache, op. cit., p. 173.

6 Heidegger, Martin: Brief über den Humanismus. Wegmarken. 2. Aufl. Frankfurt am Main 1978, p. 360 .

7 However, Heidegger also adds, "Weil man aber von dem durch Jahrhunderte genährten Vorurteil benommen ist, das Denken sei eine Sache der ration, d. h., des Rechnens im weitesten Sinne, mißtraut man schon der Rede von einer Nachbarschaft des Denkens zum Dichten." (Das Wesen der Sprache, op. cit., p. 173)

${ }^{8}$ Hölderlin, Friedrich: Der Ister. In: Hölderlin: Große Stuttgarter Ausgabe (StA). Beißner, Iriedrich/Beck, Adolf (eds.). Stuttgart 1943-85. Vol. 2, p. 192. 
Beyond such furrows are the paths Hölderlin traced along the river's sharp edges, after greeting the Garonne river and the gardens of Bordeaux, in Andenken. These paths are marked upon the southern, almost Mediterranean, veritably Greek ground Hölderlin describes from his encounter with "die tragische, einsame Erde" as he writes to his friend Böhlendorff, the land of "die Hirten des südlichen Frankreichs und einzelne Schönheiten, Männer und Frauen" and the poem recounts the slower paths traced by "Eingeschränktheit und Zufriedenheit":

1n Feiertagen gehn

Die braunen Frauen daselbst

- 1uf seidnen Boden,

Zur Märzenzeit,

I'enn gleich ist Nacht und Tag,

Ind über langsamen Stegen,

I ón goldenen Träumen schwer,

limniegende I üfte zieben.

At the year's first equinox, the silken ground of balanced time is replete with grolden dreams. The task is to think these dreams as paths for philosophy and such thinking is a music.

The music of philosophy is not a static achievement but a possibility of answering song or reflective resonance: thinking. To do this we need less the promise of singing a new song (as the achievement of thinking) than to learn to listen - for the possibility of harmony is the possibility of reticent or open attunement. This recollects the musical ideal of Greek antiquity where no one speaks who does not also at the same time listen and where the key to ethical virtue is not the imperative of law but measure or fittedness - attuned to the music of the heart, the music of life, but above all attuned to the singular possibility of attunement itself: the backstretched connexion [der gegenziebenden,

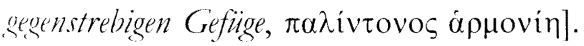

Such an attunement attends to language, nature itself, or indeed the very renture of philosophy. For to say, as Hölderlin does, "bald sind wir aber Gesang" is to propose that we may yet come to hear what is said in what is sung, as the song of praise or wonder that is the sounding shock of wonder: the ringing silence or dazzled mien of philosophic thought broken open at its inception. The paradox is not the disappointment of a misappointment, if it is also that, but inheres in any insight into what is, any astonishment before being and in the face of the nature Heidegger spent a life trying to teach us not to go beyond. The poet sings praise and in this he holds attunement in the face of the glory of simple being in the prayer which is the only truth of praise.

It is music that invites one to think in response to what is said by hearing what is said both in the words and between the lines in the style of expression 
in poetry and in philosophy as what must be learned, as Nietzsche wrote, in parallel accord with Hölderlin. This music of thought is the reason one still speaks of the very possibility of the music of the heart or, however bemusedly, of the echoing knell of sounding or attuned silence. This tuning is what Nietzsche meant when he spoke of philosophizing with a hammer - not an invitation to a reign of nihilism or self-assertive, fascist violence but an attunement in accord with Pythagoras's first musing on the differential sounds rung out by hammer blows in the blacksmith's forge: the harmony of number and the world.

From Plato to Nietzsche to Heidegger, the musical idea of philosophy is the ideal of the heights. The ethical praxis of music in philosophy is that same genius that for Nietzsche comes to teach the heart to listen by teaching it the same reticence that matters so much for Heidegger: teaching the impetuous heart that Plato despaired of holding, to stay, to dwell, to keep its peace. The music of the heart teaches the soul to hearken to not only to itself but to the many voices on that perfect day of beauty on which, as Hölderlin writes, nearly every art of song may be heard. It is the context in which, we have heard: soon, we too, shall be song: ...An einem schönen Tage läßs sich ja fast jede Sangart bören, und die Natur, wovon es her ist,
nimments auch wieder.

Viel bat von Morgen an,

Seit ein Ciespräch wir sind und hören roneinander,

Liffahren der Mensch; bald sind wir aber Gesang."

To speak of Hölderlin's song invites the silence Heidegger calls Besinnung: "Der Gesang ist die Feier der Ankunft der Götter - in welcher Ankunft alles still wird." "10 The advent of song heralds the feastday of the promised advent of gods once flown and only thus able to return. Thus, beyond converse and hearing, the song to come calls for a transfiguration of philosophy, as it requires a transfigured expression of language. This necessary transfiguration (and its failure) was the reason Heidegger's later philosophy could only shatter against the motif of style or language, for, as he wrote, "Um dem Sprachwesen nachzudenken, ihm das Seine nachzutragen, braucht es einen Wandel der Sprache, den wir weder erzwingen noch erfinden können." ${ }^{11}$ The shattering of language is a word for what may be named Nietzsche's style where the word is of necessity the poet's own word, which calls us to attend, or, as Nietzsche teaches us: having learned, to listen.

\footnotetext{
1) Hölderlin: Friedensfeier, St $\lambda$ 3, pp. 5.32 and 5.36.

"Heidegger: Das Wesen der Sprache, op. cit., p. 182. Heidegger's reflection on the silence of this

attention brought him to see saying as "Geläut der Stille", p. 30.
Ibid., p. 267.
} 


\section{Nietzsche and Hölderlin}

In 1864 (April/May), Nietzsche cites a crucial poem from Hölderlin in his early philological notebooks, followed by two shorter verses from Goethe. ${ }^{12}$ Intitled "Nachtrag zu der Stelle " $\pi \alpha \dot{\alpha} \nu \delta \dot{\varepsilon} \lambda \dot{\alpha} \mu \pi \varepsilon \mathrm{\varepsilon}$.", the entry explores a motif that would occupy Nietzsche's greater creative powers throughout his life, reflecting inveigled metaphors of light and sound, the one coloring the other and including a reference to the sounding wonder of Memnonssäule at first light, ${ }^{13}$ which Nietzsche later cites to such effect in his first book on tragedy: "der hellenische Dichter aber berührt wie ein Sonnenstrahl die erhabene und furchtbare Memnonssäule des Mythus, so dass er plötzlich zu tönen beginnt." ${ }^{14}$ Beyond the mythic manifestation of a sunbeam tuned to the resonant frequency of a lost Egyptian column of an unknown order, Nietzsche seeks to explore the metaphoric attunement of the senses: "Die Sinne des Sehens und des Hörens sind unter einander in ähnlicher Weise näher verwandt, wie etwa Geruch und Geschmack." Tracing this similarity to the common root of light and sound ("durch Schwingungen"), Nietzsche focuses upon the manifestations of this affinity in folk myth and poetry, illustrating the sensible resonance of light and sound, the metaphors for the one enhancing the other, and according to which coincidence, Nietzsche says, Apollo could be "ein Licht- und Sonnengott und zugleich der Töne Erfinder und Meister." Similarly, the young Nietzsche continued, "ganz im griechischen Geiste dichtete Hölderlin":

Wo bist du? tranken dämmert die Seele mir

I on aller deiner Wonne; denn eben ist's,

Dals ich gelauscht, wie, goldner Töne

I oll, der entž̈ickende Sonnenjüngling

Sein Abendlied auf bimmliscluer I teyer spielt;

lis tönten rings die Wälder und Hïgel nach... ${ }^{15}$

12 BAIX 2, p. 398 (April-May 1864). Sophocles, Oedipus Tyrannus (ed. Sir Richard Jebb), line 186 f.:

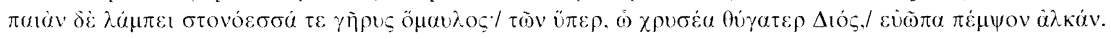
[Locb edition: $\pi u r i o v]$

1: 'Thus Nietzsche continues here: "Nuch die Sage von dem Tönen der Memnonssäule mag wohl im Grunde nichts andors bedeuten. - Das Umgekehrte, daß die Wirkung des Tones durch eine I ichtwirkung bezeichnet wird, ist vollständig durchgeführt in unster jetzigen musikalischen Terminologie. Sei es daß unsre Sprache $<\%$ > arm ist, um Schattirungen der Toneffekte auszudrücken, sei es überhaupt, daß wir, um die Wirkung von Schällen auf uns einem anderen vor die Seele zu führen, die faßlicheren und beschreibbareren Wirkungen des Lichtes als Medium gebrauchen müssen - wir reden von glänzenden, düstern, verschwommenen Harmonien, während wir in der Malerei von dem Tone des Gemäldes, von seiner Harmonic sprechen." (BAW 2, April- Mar 1864, p. 398)

1. (GT 9, KS $\ 1$, p. 67.

15 BAW 2, April-May 1864, p. 398. Citation is from Goethe's Faust. See the Nachbericht, p. 456. 
Nietzsche quotes Goethe as offering a similar metaphoric play:

Eine ähnliche Anschauung liegt zu Grunde, wenn die Sage meldet, daß die Sonne mit großem Geräusch frühmorgends aufgehe, oder wie Goethe sagt:

Tönend wird für Geisterobren

Jetžt der neue Tag geboren. ${ }^{16}$

In contrast with Goethe's purely illustrative value, Hölderlin's poem is more than apposite to Nietzsche's early reflection on the resonances of Licht und Töne. ${ }^{17}$ A jubilant expression of the soul's intoxication, a tribute of longing for a vanished god (the ellipsis continues: Doch fern ist er zu frommen Völkern, / die ibn noch ehren, hinweggegangen), ${ }^{18}$ Hölderlin's song to Apollo anticipates Nietzsche's description of the beautiful dream-birth of Apollinian vision and both Hölderlin and Nietzsche pair music with the comfort of the dream.

As he cites almost the entirety of Hölderlin's Sonnenuntergang, ${ }^{19}$ it seems evident that the poem touched a deeply resonant point in Nietzsche for the drunken, shadowed, glimmering of the soul recurs in a close to verbatim echo of the poet's song to the setting sun in Nietzsche's later Venetian Poem in Ecce bomo. ${ }^{20}$ Nietzsche sings of mourning, melancholy, evening lights, music:

16 Ibid.

17 Nietzsche traces the notion of "brilliant" sound [like hymns that "ring clear"] in musical reference as proof of the poverty of language. Nietzsche refers to the same "correspondenz von Tönen und Farbe ... Auge und (Ohr ..." in an earlier note < Ueber das Wesen der Musik.> (BAW 2, pp. 171 -172. Cf. GT 6, KSA 1, p. 48; M 426, KSA 3, p. 261). "Das Scheinende, das Leuchtende, das I icht, die Farbe. [... Der Ton stammt aus der Nacht: Die Welt des Scheins hält die Individuation fest. Die Welt des Tons knüpft aneinander: sie muß dem Willen verwandter sein." (Nachlaß 1869-70, KSA 7, 3|37|). But above all see Nietzsche's short poem from the appendix to Die Fröliliche Wissenschaft: "Fort, fort, Musik! Lass crst dic Schatten dunkeln / Und wachsen bis zur braunen lauen Nacht! / Zum Tone ist's zu früh am Tag, noch funkeln / Die Cold-7ieraten nicht in Rosen-Pracht, / Noch blieb viel Tag zurück, / Viel Tag für Dichten, Schleichen, Finsam-Munkeln / - mein Glück! Mein Glück!" (FW, Iieder des Prinzen Vogelfrei, "Mein Glück!", KSA 3, p. 648)

is Hölderlin's Dem Sonnengott makes the conncction clcarer: Ind unsre Trauer wandelt, wie Kinderschmerz: / In Siblummer sich, und wie die Winde / I Hattern und flüstern im Saitenspiele, / Bis ibm des Meisters Iinger den schönern Ton / Lintlokt, so spielen Nebel und Träum' um uns / ... (StA 1, p. 258).

1) The full text includes the following two lines: Doch fern ist er zu frommen I olkern, / Die ibn noch eliren, binneggezangen. (StA 1, p. 259).

20 See Ernst Bertram's chapter on Venice: Nietzsche. Versuch einer Mvthologie. Berlin 1918, as the background context for an ongoing discussion of this important poem in the literature including Gilman, Sander: "Braune Nacht": Friedrich Nietzsche's Venetian Poems. In: Nietzsche-Studien 1 (1972), pp. 247-270; Groddeck, Wolfram: Lin andres Wort für Musik. Zu Friedrich Nietzsches Venedig-Gedicht. In: Hartung, H. (ed.): Gedichte und Interpretationen. Vol. 5. Stuttgart 1984, pp. 18-32; Hollinake, Roger: A Note on Nictzsche's 'Gondellied'. In: Nietzsche-Studien 4 (1975), pp. 139-143; Kauffmann, Kai: Gondeln, Lichter, Musik'. Fr. Nietzsches, Venedig'-Gedicht und sein metaphorisches Umfeld. In: Nictzsche-Studien 17 (1988), pp. 158-178; Schmid, Holger: 'Nacht ist es.' Zum philosophischen ()rt von Nictzsches Venedig Gedicht. In: Nietzsche und Italien. Vin Weg von Logos zum Mythos? Tübingen 1999, pp. 95-101; etc. 
An der Brücke stand

jüngst ich in brauner Nacht.

Fernher kam Gesang:

goldener Tropfen quoll's

ïber die zitternde Fläche weg.

Gondeln, Lichter, Musik -

trunken schwamm's in die Dämmrung binaus ...

Meine Seele, ein Saitenspiel,

sang sich, unsichthar berührt,

beimlich ein Gondellied daz.,

zitternd vor bunter Seligkeit.

- Hörte Jemand ibr zu? ... ${ }^{21}$

Nietzsche's Venetian Poem offers a self-turning reflection, opening into his own converse with himself, before reversing its direction with its last, and still open, word: Hörte Jemand ibr zu? ... Echoing Hölderlin, reflecting the watcher, overhearing and overseeing distant drops of darkly shimmering gold, Nietzsche recalls the Stendhalian promise of the happiness Nietzsche always imagined to lie just beyond his grasp, like his frustrated reception as a philosopher, or as a musician, or friend, somewhere in the distance. An outsider by default, the watcher on the bridge, gives no sign either of his sense of isolation or of his responsiveness.

After Wo bist Du?, the conclusion of Hölderlin's first line, trunken dämmert die Seele mir, reappears in Nietzsche's conclusion to his first strophe: trunken sclowamm's in die Dämmrung binaus .... The golden sound of sunset ${ }^{22}$ is the sound of transfigured light, changing to evening twilight and to night, echoing in the brown, burnished dark and idle reflections of Nietzsche's song in the city of bridges. In its place and its time at the end of day, the disposition of Nietzsche's later poem reprises the occasion of Hölderlin's tone-setting answer to the deep resonance of the sunset and the image now heard in Venice, replying, calling again for an echoing song. We hear not merely the same sonorities in the words of the two distant poems: Hölderlin's goldner Töne [/ Voll,] in Nietzsche's goldener Tropfen [quoll's] - or the same play of words and meaning - [bimmlische/Seligkeit], Lgelauscht/zitternd] - which resonant echo would be sufficient to suggest that Nietzsche had at least kept the memory of this poem at the heart of a life of thinking on music, but much more the flow and the structure of the cited fragment bears comparison to the directed structure of Nietzsche's poem. Hölderlin writes

21 I:H, Warum ich so klug bin 7.

22 Nietzsche's quotation in the same context of Goethe's lines on the clang of sunset did not have the same effect on him, even if we take into account the reference from the Rig I eda as prelude to an entire book on the subject of the rising sun or the dawning day in Morgenröthe. 
...denn eben ist's,

Daß ich gelauscht, wie, goldner 'Töne

Voll, der entzückende Sonnenjüngling

Sein Abendlied auf himmlischer Leyer spielt.

In darker, browner evening, ${ }^{23}$ the same lyre play of Apollo's golden youth is transformed for Nietzsche into his very soul: An der Brückee stand/jüngst ich in brauner Nacht. The song heard from afar, Fernher kam Gesang, heard as the echo of the swelling soul, recalls Hölderlin's song trembling its intoxication now in a more liquid resonance in Nietzsche's fluid play of sound and golden droplets and the distant cradles of magical gondolas gliding beyond sight in the twilight:

goldener Tropfen quoll's

über die zitternde Fläche weg.

Gondeln, I ichter, Musik, -

trunken schwramm's in die Dämmrung binaus ...

Nietzsche's entire soul resonates in trembling, attuned response to the golden drops welling on the surface, the gondolas, lights, and the music of the evening:

Meine Seele, ein Saitenspiel,

sang sich, unsichthar berïhrt,

beimlich ein Gondellied dazu,

zitternd vor bunter Seligkeit.

In this way, the most significant gondola song, answering more than the calls along the distant corridors of Venetian canals, would be the song between Hölderlin and Nietzsche. Like Nietzsche's image of the voices echoing from proximities that may only resound from mountaintop to mountaintop, which Heidegger later appropriated to exemplify the nearness of greatness, Hölderlin's call resounds in Nietzsche's soul: Wo bist Du? ..., calling forth an answering song leaning on his bridge in Venice, in the bronzed, southern night of his own soul - ein Saitenspiel, as he names it, - singing a gondola song in reply to the one heard - and in the remembered tone, poised above the night waters of Venice on the bridge of life itself (and in the pensive wake of a still present death, which had silenced, as death quietly does, the possibility of reconciliation, but not the possibility of framing the answer that can only be sung to a long

2.3 Gilman has an extended reflection on this term which Kauffmann cites in contrast with Groddeck and with further reference to an earlier study by Viëtor, K.: Die Barockformel 'Braune Nacht'. In: Zeitschrift für Philologie 63 (1938), pp. 284-298. This is the same colour term Nietzsche evokes in a letter to Rohde. It is, I am informed, a Wagnerian reference as well. See Bertram, et al. above. It may be noteworthy that the brown of the night, in addition to its violet and amethyst overtonality of twilight, allows the English compound brom'n study' defined by the Oxford Iinglish I Dictionary as "a state of mental abstraction or musing; esp. reverie." 
and irretrievably alienated friend) ${ }^{24}$ and calling for a reply in turn - Hörte jemand ibr zu? ...

Hearing such a resonant converse between poet and thinker, the poem Nietzsche cites in his notes from 1873 would become the watchword for his life as the motto taken from Pindar's second Pythian ode: "Гévoto oíos ž $\sigma \sigma l$ $\mu \alpha \theta \omega \dot{v} . "{ }^{25}$ Nietzsche's Pindarian, paradoxical imperative, "Du sollst der werden, der du bist" (FW 270), recurs as the subtitle to his auto-bibliography, Ecce homo. Wie man wird was man ist. The context of the 1873 poem, contra what is usually noted as a reservation against Nietzsche's rendering of Pindar, suggests that Nietzsche might have found it redundant to translate the mathematical measure of being. The arched bow in Hölderlin is collapsed to the mystery of becoming in

Nietzsche's citation:

„Ein Räthsel ist Reinentsprungenes. Auch

Der Gesang kaum darf es enthüllen. Denn

Wie du anfingst, wirst du bleiben,

So viel auch wirket die Noth

Und die Zucht, das Meiste nämlich

Vermag die Geburt

Und der Lichtstrahl, der

Dem Neugebornen begegnet." Hölderlin. ${ }^{26}$

These lines from Hölderlin: So viel auch wirket die Noth/Und die Zucht, das Meiste nämlich/Vermag die Geburt/, frame Nietzsche's Pindarian word. With reference to Zucht, those who carefully mark Swabian tonalities can tell us what resonant emphasis is conveyed by the words following at the end of the line - das Meiste nämlich - recalling the Nietzschean sense of Werden against Hölderlinian and Heraclitean Vergehen. Nietzsche's style entails the elided sense of rule ( $D u$ sollst der werden) and measure (Wie man wird ...). Thus Alexander Nehamas's exactly fine translation of Pindar complements Nietzsche's rendering: "Having learned, become who you are." ${ }^{27}$ Needfulness and what is needed, the whole of one's beginning, means that one can only keep true to one's start, or as Hölderlin also says, Doch es kehret umsonst nicht / Unser Bogen, woher er kommt. ${ }^{28}$

24 See Bertram, op. cit., pp. 289-290 and ff., for a discussion of the complex array of references to Wagner.

25 Cf. Pindar, Pyth. 2, 72. It should be noted that while quietly resolving many of the philosophical debates that grew up in the wake of Alexander Nehamas' Nietzsctbe: Life as Literature (Cambridge debates that grew up in the wake of Alexander Nehamas Ne Nehamas also offers a finely lapidary
1985), as well as a few incidental ones for good measure, Ne Socratic Reflections from Plato to
rendering of Pindar in his recent book: The Art of Living. Sho vou are." Foucault. Berkeley 1998, p. 128. "Having learned, become who you are."

26 Nachlaß 1873, KSA 7, 29|202]. Citation of Hölderlin: Der Rhein. StA 2, p. 143. Nietzsche also Nachlaß 1873, KSA 7,29 202]. Citation of Hebt das Lebendigste." And at the end, we shall have
cites Hölderlin's "Wer das Tiefste gedacht, liebt
occasion to mark the recurrence of this in no less a locus than Zarathustra (end of Book 3).

27 Nehamas: The Art of Living, op. cit., p. 128.

28 Hölderlin: Lebenslauf. St $\Lambda$ 2, p. 22. 
Where Hölderlin and Nietzsche and Heidegger invoke the ideals of feast, celebration, and joy in precise connection with thinking or philosophy, how are we to read Nietzsche's ultimate transfiguration of philosophy as a festival of thought (or art) exactly between Hölderlin and Heidegger? I seek to explore this complex constellation as the dynamic play of affinity and influence regarding the manner in which Nietzsche's own writing (that is, particularly his provocatively "poetic" style) may be seen to have transformed not only the literary possibilities but also the critical basis of philosophy and therewith, again, and only perhaps, the potential of what may be thought as philosophy.

\section{Influence and Interpretation}

Hölderlin's mark on Nietzsche is both brighter and more complex than Cosima Wagner's alarmed report. ${ }^{29}$ Writing, as we have just seen, his most beautiful poem in Hölderlin's own tone - after copying it down in his notes, quite possibly from heart, many years earlier - Nietzsche also patterns his greatest work on Hölderlin's fragments for the tragic drama Der Tod des Empedokles. ${ }^{30} \mathrm{But}$ Nietzsche also seems to disappoint this same influence for he seems unable to resist mocking the name and much more, ${ }^{31}$ as Nietzsche similarly compromises himself - the way he compromises everyone, the way Heidegger notoriously overreads the history of philosophy. And yet, part of Nietzsche's protean style is that he is thereby also able to give the lie to his own posturing bravado (and,

29) Cosima's notes betray an obvious anxiety of influence upon the (i. e., concerning the right influences on the impressionable) energies and thoughts of a tame or pet philosophy professor.

30) Nicholas Martin in his book Nietzsche and Schiller: Untimely. Aesthetics (Oxford 1996) notes the parallels in language and ethos between Nietzsche's Zarathustra and Hölderlin's Hyperion, pp. 132-133. See also: Bertallot, Hans Werner: Hölderlin-Nietzsche. Untersuchungen zum hymnischen Stil in Prosa und Vers. Berlin 1933; Nendeln/Liechtenstein 1967.

31 Thus in the Summer/Fall of 1884 Nietzsche, all-to()-attentive to the banality and significance of what he caricatures as an absurd downgoing, writes: "Die Art Hölderlin und Leopardi: ich bin hart genug, um über deren Zugrundegehen zu lachen. Man hat eine falsche Vorstellung davon. Solche Ultra-Platoniker, denen immer die Naivetät abgeht, enden schlecht. Irgend Etwas muß derb und grob sein am Menschen: sonst geht er auf eine lächerliche Weise zu Grunde vor lauter Widersprüchen mit den einfachsten Thatsachen: $\%$. B. mit der Thatsache, daß ein Mann von Zeit zu Zeit ein Weib nöthig hat, wie er von Zeit zu Zeit eine rechtschaffene Mahlzeit nöthig hat. Zuletzt haben die Jesuiten herausgebracht, daß Leop<ardi $>$ - - " Nachlaß $1884, \mathrm{KS} \backslash 11,26|405|)$. He completes the ellided aposiopesis a bit later, which makes the parallel tediously clear: "Gegen den falschen Idealismus, wo durch übertriebene Feinheit sich die besten Naturen der Welt entfremden. Wie schade, daß der ganze Süden Furopas um die Vererbung jener gebändigten Sinnlichkeit gekommen ist, durch die Abstinenz der Geistlichen! Und daß solche Shelleys, Hölderlins, Leopardis zu Grunde gehn, ist billig, ich halte nicht gar viel von solchen Menschen. Is ergötzt mich, an die Revanchen zu denken, welche die derbe Natürlichkeit der Natur bei solcher Art Menschen nimmt $\%$ B. wenn ich höre, daß $\mathrm{L}$ < e opardi> früher ( n < anie> tricb, später impotent war." (Nachlaß 1885, KSA 11, 34[95]) 
for a man who comes to an end in a putative madness so many name similar to Hölderlin's own surmised destiny, this is exactly an excess of identification), reprising his early allusion to the spirit of Hölderlin's shining paean to the music of antiquity as late as Ecce homo.

With the thumos of a seventeen year-old, Nietzsche's enthusiasm for his "Lieblingsdichter" (October, 1861) betrayed not only an absorbing passion but a self-righteous, self-identifying and thereby it is to be thought, self-transfiguring reading of Hölderlin's writings. ${ }^{32}$ Traces not only of the famed Hyperion but also the drafts for a tragedy on what Nietzsche called the "divine" death of I:mpedocles, ${ }^{3.3}$ as well as Hölderlin's poetry, echo throughout Nietzsche's works. Beyond Nietzsche's subjective but accurate polemic against the standard account of Hölderlin's unclarity and disqualifying madness, both Hölderlin's antiquity (Sophocles and Pindar) and his noble and tragic sensibility vis-à-vis the modern constituted a key element in Nietzsche's formation.

In fact, Nietzsche's school letter sketches the plan he later develops into I)avid Strauss der Bekenner und der Schriftsteller, the first of his Unzeitgemässe Betrachtungen: each of which, we recall, and not only the essay on Schopenhauer, may be counted as reprising Nietzsche's Bildung or the formative influence of his "educators," his Erziehern. ${ }^{34}$ Inverting the aesthetic claim against Hölderlin by showing the unthinking basis of such critical denigration, Nietzsche outlines an early genealogy of what he later names ressentiment and he claims that such prejudicial denigration, as he will always claim and especially in his own regard, is the consequence of a lack of knowledge of the author's work in its entirety

\footnotetext{
See: Bothe, Henning: «Iin Zeichen sind wir, deutungslos». Die Rezeption Hölderlins von ihren Infangen bis zu Stefan (ieorge. Stuttgart 1992. Bothe fails to take account of Nietzsche's complex relation to his own "influences." Thus although Bothe notes the importance of Nietzsche for Hölderlin's Rezeptionsgeschidote, he completely misses the critical element of Nictzsche's "style" with his assertion that "Was Nietzsche über Hölderlin ausdrücklich sagt, geht nicht über das hinaus, was seit der Romantik tradiert wurde" (p. 53), although Bothe emphasizes Hölderlin's deep influence on Nietzsche.

¿ Nietzsche's 1/so sprach Zarathustra recalls Hölderlin's typerion in its best tonalities, especially the elevated or transfigured tone to be heard at the end of the second part of Hyperion. And a number of scholars have written on the relation between Zarathustra and Hölderlin's "Kimpedokles." See Note 76, below. Vivarelli, Vivetta: Empedokles und /arathustra. Verschwendeter Reichtum und Wollust am Untergang. In: Nietzsche-Studien 18 (1989), pp. $5(19)-536$ critiques Söring, Jürgen: Incipit Zarathustra - Vom Abgrund der Zukunft. In: Nietzsche-Studien 8 (1979), pp. 334-361 as overlooking the parallel between Hölderlin's Empedocles and Nietzsche's Zarathustra ("es entyeht ihm jedoch die Parallele zu Hölderlin, obwohl er ihn mehrmals zitiert" Note 19, p. 522). For her own part, although she footnotes the whole of Nietzsche's citation of Hölderlin's Sonnenuntergang and refers it to the context of Apollo as such, Vivarelli makes no connection between Hölderlin's poem and Nietzsche's later work - concluding, with reference to the notebooks from 1883, "Is ist jedenfalls bemerkenswert, daß sich in der Gruppe 13 fast alle Hölderlinischen Reminiszenzen finden", Note 12, p. 514.

it UB, David Strauss der Bekenner und der Schriftsteller 2, KS $\Lambda$ 1, p. 172.
} 
or as such: to understand Hölderlin (Nietzsche), to be able to talk about Hölderlin's (or Nietzsche's own) work, one needs to have read it, all of it.

Thus Nietzsche identified a literal, exact barbarism in the spirit and substance of negative judgments concerning Hölderlin, in order to raise the same genealogically formal objection to Friedrich Vischer's condescending account of Hölderlin. Against Vischer's condescension - clucking of Hölderlin "es fehlte ihm als Waffe der Humor".35 - Nietzsche deploys a challenge requiring considerable nuance beyond the reduction of Nietzsche to the laughing philosopher ${ }^{36}$ (a judgment that goes far to capture Nietzsche's appeal to so many and so many different readers: he teaches us to laugh, commentators tell us, he brings "a sense of humor to philosophy") ${ }^{37}$ - for philistinism entails the same sense of humor Vischer advocates and exemplifies the tactic of mockery which some readers of Nietzsche prefer. Mocking provocation is the very definition of the philistine, that is - so Nietzsche in turn polemicizes beyond Vischer and his peers - the cultured barbarian captures the essence of philistinism itself. And Nietzsche shared this sombre insight with Hölderlin. This cultural philistinism is what Germans are, this distant fantasy was Greece, here is what was and here is what is, and - far more than historical methods and more critical than historical accuracies - what can be lies shattered in the shadowy hiatus of thick and unthinking barbarism in the between that endures beyond the mere separation of time.

Celebrated today not merely as one of but as perhaps the most profound of poets, of unquestioned rank, Hölderlin was not always so regarded: not during his lifetime, be it before or after his flight from the discourse of the public realm, and not thereafter. For more than half a century, where there is any judgment at all, the standard scholarly judgment of Hölderlin's poetry con-

35 Ibid., p. 164.

36 Nietzsche's strategic critique here is usually ascribed to his youth. Later, commentators are quick to claim Nietzsche's own voice on the side of a necessary sense of humor as a prelude to his ultimate provocative and insouciant image as the "laughing philosopher." But Nietzsche promised less to teach us to laugh (this isn't even Archilochus's promise) than he proposed to his readers the very different challenge of learning to laugh at oneself - "wie man lachen müsste," as one would have to laugh, "um aus der ganzen Wahrheit heraus zu lachen" (FW, Erstes Buch 1, KSA 3, p. 370). Nietzsche's laughter is no less serious than his reflections on play, that is on music and tragedy. See, a bit later in Jenseits l'on Gitt und Böse, Nietzsche's counterintuitive musing on the "Reife des Mannes: das heisst den Iirnst wiedergefunden haben, den man als Kind hatte, beim Spiel" (JGB 94). Here the emphasis is less on playfulness, or the adult fantasy of the lightness lost in childhood than the extraordinarily earnest quality of childhood and its unremitting lack of irony.

37- Sec: Kunas, Tarmo: Nictzsches Lachen. Iin Studie über das Komische in Nietzsches Werken. München 1982, as well as a series of earnest enthusiasts for the Nietzschean sense of humor, the names of whom can be generated almost at random. But see, for recent examples: Higgins, Kathleen Maric: Comic Relief. Nietzsche's Gay Science. Oxford 1999, and the collection edited by Lippitt, John: Nietzsche's Futures. Houndmills, Basingstoke 1999. 
demned it as obscure - very much in the same way and for the same reason that Heidegger's philosophy is popularly condemned. Hölderlin's interest in antiquity (together with his pantheism) was rejected as less than properly or decently "German."

Norbert von Hellingrath's Promethean venture removed Hölderlin's oeuvre from the guarded reserves and the critical esteem of his more conservative editors (and scholars from Vischer onward), setting a new aspect of the poet before a new generation of war-sobre eyes and revitalized judgment. ${ }^{38}$ But when Nietzsche wrote, the apotheosis of Hölderlin (crowned in the blood of two wars), was unimagined at a time when hardly any one but the most esoteric scholar, German or otherwise, knew Hölderlin's name. ${ }^{39}$ Like scholarly judgments on Nietzsche himself, the greater part of comparative judgment on Hölderlin remained qualifiedly slighting, nor did this judgment simply vanish with von Hellingrath's publication of the late work of so-called madness, though, and to be sure it began to change with the George circle (if this change swung toward the Charybdis of all-too-excessively German Nazi alliance), or, to name the philosophers, Dilthey (who called Hölderlin a visionary or "Seher") or Jaspers (as the philosophical and scientifico-medical counterpart to Stefan Zweig, exemplifying the lasting influence of psychoanalytic judgment, today derived, at one fashionable extreme, by Jean Laplanche from Jacques Lacan, and originally articulated in terms taken from Freud and Jung, for Zweig and Jaspers). And the poetic lustre or frisson of madness continues to be imagined as Hölderlin's distinguishing characteristic. Such a romanticism of romanticism (still in force in both Hölderlin and Nietzsche studies), meant, for von Hellingrath, that Hölderlin would bear the heroic mark of mantic, that is, divine enthusiasm: "Wer so unter Göttern lebt, dessen Rede verstehen die Menschen nicht mehr..."40 Scholars ranging from Lange to Cassirer to Lukàcs, would (and do) continue to fit Hölderlin into the quasi-divine (and given Socrates' discussion in the Apology and in the Phaedo: within the very philosophically respectable) lineage of madness. For his part, Heidegger would develop the relationship between philosophy

34 This in a distant way is responsible for the caution with which scholars speak of the Hölderlin editions, just because, they tell us, like Beißner's edition, new editions of Hölderlin seem regularly underway - just as Nietzsche's works themselves underwent several different instaurations according to particular visions, and some might argue for vet another editorial venture, or at least a complete edition of the current edition of Nietzsche, in this same spirit.

3. Cf. Böschenstein, Bernhard: Leuchttürme. Von Hölderlin zu Celan. Frankfurt 1977; Pellegrini, Alessandro: Friedrich Hölderlin. Sein Bild in der Forschung. Berlin 1965; as well as Ingo Seidler's review: 'Stifter einer weiteren $\lambda$ hnenreihe'. Hölderlin's Influence on German Poets of the Twentieth Century: In: George, Emery E. (ed.): Friedrich Hölderlin: An Early Modern. Ann Arbor 1972, pp. 64-86.

41) Hellingrath, Norbert von: Hölderlins Wahnsinn. In: Hölderlin. Zwei Vorträge. Hölderlin und die Deutschen. Hölderlins Wahnsinn. München 1921, p. 62. 
and poetic language implied in von Hellingrath's claim: "zum ersten Male in Deutschland wagt sich Dichtersprache so unverstellt vor, ganz aus heimischen Grund, in heimischer Luft gewachsen, so sehr auch das griechische Vorbild Not war, dem Dichter Mut zu machen zu Gleichdichterischem." 41

The historical association with Nazism is wrongmindedly persistent (it is claimed, in a damnable inaccuracy, that Hölderlin's hymn Germanien required deliberate elision in order to be useful in a time of war). ${ }^{42}$ Hence, given Heidegger's political history, Heidegger's apostrophising of Hölderlin's essence and rank, "Dichter der Deutschen," 43 continues to be read as if Heidegger were expressing nothing but a party or Nazi enthusiasm for the poet. ${ }^{44}$ But beyond the political convenience which encourages such contentions, after Nietzsche, ${ }^{45}$ Heidegger was one of the first scholars to regard Hölderlin as poet without coordinately aligning his poetry (be it as pathology or divine mark) with madness. ${ }^{46}$ For Heidegger, and schlechthin, Hölderlin is the "Dichter

+1 Ibid.

42 The historian, Gordon A. Craig, in his The Politics of the Inpolitical. German Writers and the Problem of Poner $1770-1871$ (Oxford 1995), repeats David Constantine's claim that in quoting Germanien, the word "wehrlos: is deleted in the penultimate line" (p. 110). Constantine writes: "(One specific instance of Nazi abuse of Hölderlin is Hermann Binder's quoting the last lines of this poem
with the word "wehrlos' omitted." Constantine with the word 'wehrlos' omitted." Constantine, David: Hölderlin. Oxford 1988, p. 257. In the
note to this comment, Constantine cites Binder's Deutschlond.

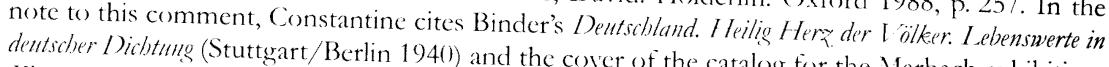
deutscher Dichtung (Stuttgart/Berlin 1940) and the cover of the catalog for the Marbach exhibition,
Klassiker in finsteren Zeiten (1983) "in which the word "wchrlos' is crossed out" Constantine inaccurately represents both pointe word "wchrlos' is crossed out." (p. 326, note 17). to the Marbach catalog cover which, as a collage, was a pastiche, an illustration dramatizing the theme of the exhibit, not historiography:

4.3 Heidegger, Martin: Hölderlins Hymnen "Germanien" und "Der Rhein". Gesamtausgabe. Vol. 39. Frankfurt am Main 1980, p. 214. 44 Thus Craig professes his horror at contemplating what he calls the Scylla and Charybdis of
Hölderlin as "interpreted by Martin Heidegger and protected by Josef Goebbels." Craig: The
Politics of the Unpolitical, op. cit., p. 110 . Politics of the Unpolitical, op. cit., p. 110.

45 Geerd I.crnout reviewing I lölderlin's reception in the $19^{\text {th }}$ and $20^{\text {th }}$ centuries, offers the important reminder that in his day, Nietzsche was "only a marginal figure" and hence the reception of Nietzsche's "comments on Hölderlin would only gain importance after Nictzsche's death" - that is, only after a similarly blocked set of obsctacles to understanding Nictzsche himself had been, as they are still not entirely, weathered down. Jernout, Geerd: The Poet as Thinker. Hölderlin in France. South Carolina 1994, p. 4. I.ernout cites Nllessandro Pellegrini's claim that the key to Nietzsche's reception of Hölderlin lies in his broader cultural program the ideal of a return to (ireece, betraying what has been called the nostalgia of Germany for Greece (Taminiaux, see reference below) or the tyranny of Grece over (iermany: For Pellegrini, "Hölderlins Werk wurde besser verstanden, nachdem es durch Nietzsche erläutert worden war." (Friedrich Hölderlin, op. cit., p. 39) This is the claim Bothe opposes and I.ernout qualifies but it is perhaps
better to suggest a reading of Nietzeng defense of the poet, despite Nietzetzehe's reception of Hölderlin not as an introduction to or

regard to the singular resonance of Hölderlin's influence in Nictzsche's work.
th Hans-Georg Gadamer claims Heidecorer's reading as here, with

"forces us to decide." Gadamer, Hans-Georg: Von der Wahrheit des Worterally so, for Heidegger Denken bei Martin Heidegger. In: Jahresuabe der Martin-Heiderser-(iesellschaft pp. 7-22. See also Lernout's declaration that "Heidegger's influence on Hölderlin criticism in 
des Dichters" 47 - even if naming him as such arraigns him not only with Goethe and Schiller, Klopstock and Heine, Rilke and Benn, but above them all, reigning as poet's poet: a prince of the veritable word.

For this reason, Eckart Förster both accurately and usefully prefaces the Inglish edition of Dieter Henrich's reactive (contra-Heidegger) study of Hölderlin's Andenken, with a leading reference to the importance of Heidegger's reading of Hölderlin - thereby inadvertedly contradicting Henrich's de-constructive strike against Heidegger's earlier and famous reading of that poem. For it is more than parenthetically significant that Henrich himself fails to mention Heidegger by name - just as he fails to cite any but only small excerpts from Hölderlin's poem in his reading of it, thereby effectively excluding Hölderlin just as neatly as he leaves Heidegger out of his text. For his part, and like Gadamer, Iörster relates Heidegger's priority in Hölderlin's scholarly reception for the benefit of an English language audience. Citing Nietzsche as the "philosopher who set the stage for the Hölderlin renaissance in our century," 48 Förster confirms the importance for Heidegger of von Hellingrath's edition as "an earthquake," ${ }^{4 \prime}$ in Heidegger's words (these are the same words Stefan Zweig employs, recalling not only Nietzsche's own description of Hölderlin's Hyperion as a turbulent wave crashing over him, ${ }^{50}$ but Hölderlin's own account of the self-transformation effected by his sojourn in Bordeaux, "und wie man Helden nachspricht, kann ich wohl sagen, daß mich Apollo geschlagen"). ${ }^{51}$ Thus Förster situates the critical and "perhaps unique" importance of Heidegger's reception of Hölderlin. Beginning with his 1934-35 lecture courses (held directly in the wake of Heidegger's failed debut as Nazi rector), Förster writes that Heidegger "entered into a dialogue with the poet that continued throughout his life," whereby "Hölderlin represents the alternative to the entire metaphysical tradition that reaches its peak in Hegel's system." 52 In specific and contrasting focus, Ilenrich's interpretive project opposes Heidegger's reading, both as an account of his poetry and as philosophy, reclaiming Hölderlin, at least in theory, and qua theorist, to be installed within the frame of idealist philosophy, vis-à-vis Kant, Hegel (and Schelling), and Fichte (Schiller and Goethe, as well as Reinhold). In this way, Henrich proposes that we understand Hölderlin from the perspective

the fifties and sixties in West Germany cannot be exaggerated." Lernout: 'The Poet as 'Thinker, op. cit., p. 13.

4- Heidegger, Martin: Frläuterungen zu Hölderlins Dichtung. Frankfurt am Main 1971, pp. 32-34.

t\& Förster, Eckart: Preface. In: Henrich, Dieter: The Course of Remembrance and other Essays on Hölderlin. Stanford 1997, p. 2.

+4) Ibid., p. 4.

5 Nictzsche: "wic der Wellenschlag des erregten Meeres." (BAW 2, p. 2). Zweig, Stefan: Kampf mit dem Dämon. Hölderlin. Kleist. Nietzsche. I ceipzig 1925.

51 Hölderlin: St $\Lambda$ 4, p. 432.

52 Förster: Preface, op. cit., p. 4. 
of idealist philosophy, hearing his poetry under the same constraints. It is hardly any wonder that Henrich refuses the poet a voice in his interpretive text where the poet's own words might have opposed the cogency and the appeal of such a reductive (and it is a reductive) claim.

\section{Language and Thought Between Hölderlin and Nietzsche}

Hölderlin's own tragic reflection is the most significant source of Nietzsche's rethinking of the nature of tragedy as it is brought to word in Nietzsche's fatal, philological debut, Die Geburt der Tragödie aus dem Geiste der Musik. Because the music at the origin of tragedy, as Nietzsche writes, is "nur aus ihren Niederschlag als Lyrik uns Bekannt," the keys to tragedy in Nietzsche's reading are the studies in rhythm Nietzsche plans but never brings to professional publication in the context of his studies of language, together with the figure of the philosopher Empedocles (whom Nietzsche yokes with tragedy) again and exactly via Hölderlin:

Für die stete Wiederholung $-U-U$ usw. den Rhythmus der Reim-Dichtung sind wir musikalisch zu anspruchsvoll (vom mißverstandenenen Hexameter noch abgesehen!) Wie wohl thut uns schon die Form Platens und Hölderlins! Aber viel zu streng für uns! Das Spiel mit den verschiedensten Metren und zeitweilig das Unmetrische ist das Rechte: die Freiheit, die wir bereits in der Musik, durch $\mathrm{R}<$ ichard $>\mathrm{W}<$ agner $>$, erlangt haben! dürfen wir uns wohl für die Poesie nehmen! Zuletzt: es ist die einzige, die stark zu Herzen redet! - Dank Luther! (KSA 11, 25[172])

That Nietzsche is able at the same time to hear the same key in Wagner's music proves the metonymy of thinking itself. And this metonymy reminds us that the resonance of thinking always entails thinking more than one thing by and with a single word.

In the same associative fashion, Heidegger found himself compelled to turn both to Nietzsche and Hölderlin for the sake of his post-rectorial articulation of what he called his own Beiträge zur Philosophie. The constellation is significant both for understanding the limits of Heidegger's negative reading of Nietzsche and the depths of Heidegger's reading of Hölderlin in terms of the key proximity between thinking and poetry but also in terms of Heidegger's later and maligned silence. This constellation likewise provides the key to Heidegger's contention that it would be no one but Nietzsche who would destroy him in the end ${ }^{53}$ not his own (badly misjudged) Nazi enthusiasms nor the Nazi politics on a

\footnotetext{
5.3 Gnomically, Heidegger's most famous philosophical student, Hans-Georg Gadamer has recounted Heidegger's confession, Nietzsche hat mich kaputt gemacht to any number of students and visitors. Yet, the master of hermeneutics has not ventured an interpretation of Heidegger's declaration, beyond his endorsement of its amusement value.
} 
banal and real level that had stripped him of power and influence as swiftly and briefly, passingly, as they had, one month for every year of the Reich, once elevated him to power.

Where Heidegger acknowledges Hölderlin as "Dichter des Dicbters," he grants Nietzsche nothing like a parallel accolade. ${ }^{54}$ This is not only because Heidegger means to requisition the title of thinker par excellence for himself. For it is routinely claimed that Nietzsche is only, i.e., that Nietzsche is no more than, or just, a poet. This claim offers not only a negative judgment of Nietzsche's quality as (his identity or being) a philosopher in a convicted (dominant and ruling) climate of analytic (theoretical, logical- and science-minded) philosophy. From the beginning, Nietzsche himself (qua Zarathustra) originates the judgment in his own case (such a critical dependency on the author himself for the terms of interpretation - however bastard - may be confirmed as the dominant conventionality or trope of Nietzsche reception throughout the past century). Taking on himself the same sobriquet (only a poet) - subsequently employed as a lever and a wedge to separate Nietzsche's works from "real" or professional, self-serious philosophy - Nietzsche himself is the first source of his own "outsider's" status. Thus Nietzsche, at times, may be named a poet to denigrate his work, just as the same term, at other times, may be invoked to elevate his works "above" philosophy with the result that Nietzsche is not (Nietzsche is still not) typically read first and foremost as a philosopher, which in turn inevitably leads to the correlevant effect that Nietzsche's writings, as "poetry," have also been and still remain exposed (as philosopher's writings are rarely regarded as fully liable to, as fully needing) the labours and analyses of literary scholars. ${ }^{55}$

As Zarathustra, Nietzsche teases himself as only fool, only poet. Thus Nietzsche speaks as one positioning himself in proximity to the greats of history, taking himself as related to the rare. But to say this is to recall that Nietzsche names himself, qua Zarathustra, "nur Narr, nur Dichter" in his most elevated, in his most abandoned or loneliest moment. In this loneliness, Nietzsche held

5. Nietzsche bears the distinction in Heidegger's philosophy, of being named in a key context and over and over, as philosopher among philosophers, i. e., as one "who knows what philosophy is." This is a singular distinction because it is not one automatically granted Nietzsche either by Heidegger's peers or philosophers today. To claim Nietzsche as a philosopher without qualification, but at its apex, taken in a climate of professional philosophy and scientific scholarship and natural or real scientific discovery in the nineteenth and twenticth century, is to say a great deal.

5. Unlike Kant, unlike Hegel, unlike Schopenhauer - despite the latter's exemplary literarity Nietzsche is analysed by literary scholars who see what he writes as they see the writings of Robert Musil or Alfred Döblin or Thomas Mann and so on. Musil, Döblin, Mann all say philosophical things, about philosophical themes. Is Nietzsche not the same? Thus we have the continuing question in Nietzsche studies concerning the correlevant position of philological exegesis and philosophical analysis. In a nicely Empedoclean trope, the dominion of the one appears to entail the eclipse of the other. 
discourse, spoke most deeply to himself, as he had earlier, before Zarathustra, rhymed to himself in a ticktock charm: "Ja, mein Herr," becoming, through this same discourse with himself, his own best friend, "Sie sind ein Dichter." Best friends know how to tell the truth, it is said, and this may be so even when that best and only friend is one's soul.

Patently, and this itself is fuel for an industry that revives the romantic vision of the genius, this same ideal of fool and poet in Nietzsche's words expresses the vision of the solitary (and with this: the madman), so that, of course, Hölderlin too would have and would keep this loneliness to the extreme condemnation of some forty years of it; for his part, Heidegger would win it by turns and turns until he learnt to keep true to the silence he told himself as related only to the rare, i. e., with Nietzsche and with Hölderlin, related only to the Greeks. This story of poetry and solitude is also the story of nature, it is the story of tragedy and it is the story of politics read, in order to be tragedy, in terms of love. It is Heraclitus and Sophocles, Pindar and Empedocles, Socrates and Alcibiades (that is, in Nietzsche's language, we may count Socrates in this register if we regard Socrates mythically, in terms of his own mythic projection, as Nietzsche named him the greatest of erotics).

\section{Germany and Greece: The Ground of Empedocles and the Tragic Ideal}

Nietzsche stands between both Hölderlin and his archaicizing relation to the forgotten deities of Greece and Heidegger's assertion of the essential relation between Germany and Greece. For Heidegger, this complex question is adumbrated via the special affinity Heidegger declares between Germany and Greece, an affinity Heidegger finds, as he ultimately finds everything, in language. External perspectives variously name this affine relation the "tyranny" of Greece over Germany (as in E. M. Butler's still indispensable book on the subject) or "nostalgia" of Germany for Greece (to use Jacques Taminiaux's own carefully philosophical reprise of the classicism of German idealism and thought at the turn of the century that irrevocably links the fortunes of the nineteenth to the eigtheenth centuries). ${ }^{56}$ Recently, the wake of the Farias scandal exposed another dimension of this affinity between Germany and Greece, equal parts vulnerability and reactively nationalist sensibility on the part of recent French (especially literary, to wit: Philippe Lacoue-Labarthe, Jean-Luc Nancy, etc.) readings and

56 Taminiaux, Jacques: Le nostalgie de la Grèce à l'aube de l'idéalisme allemand. The Hague 1967. See also 'Taminiaux's recent $I_{e}$ théatre des plilosophes (Grenoble 1995), where he discusses in three successive chapters, Nietzsche (in the context of Die Gelburt der Tragëdie), Heidegger, Sophocles, and the pre-Socratic philosophers, and, finally, the shadings of Aristotle in Hölderlin. 
English and American interpreters. This contrast betrays the primacy of interpretation over philosophy but above all it is meant contra Heidegger's reading of Hölderlin (and Nietzsche). This is the inherent didacticism of recent debates on the national or the proper (what is ownmost to the Germans - or to the French, the English, the Americans, and, not incidentally, the Asian: brought out of occidental marginalization only to be obliterated again in a collective national assignment). ${ }^{57}$ Above all, such debates are meant to remind the reader that Heidegger's focus on the specifically, identifiably, regionally German in Hölderlin's poetry is a massively unhappy emphasis, an historically fatal mistake. Thus as can be seen in Peter Szondi, Andrzej Warjminski, etc., the ethical topos of the oriental (the utterly Other, as the terminus conveys an imaginary image of alterity indebted to Levinas rather than - it is to be regretted, for there are affinities here if only we could begin to find them - to Hölderlin) is posed as the true nature of antique Greece, whereby the Greeks come to be rendered more African (Egyptian or Asian), than Aryan (geschweige Deutsch). 'The associative play governing all such national namings and alliances need not (cannot) interest us here, nor indeed the question of whether it is or could be correct to trace the origins of Greece to the Orient (or substitutable Egyptian/African) but instead to note that the key to such a reading seeks to establish not merely that the Greeks are "foreign [fremd]" to us, as Hölderlin already wrote, but utterly and (polemically presented as Hölderlin's insight into the orientalism of Greek antiquity) precisely "other." 58 Nor would I seek, in a context including Nietzsche as much as Hölderlin and Heidegger, to argue against this radical difference exactly as the Hölderlinian difference between what is one's own and what is foreign as it is expressed in the Heideggerian context of open appropriation. That is the challenge of culture from Goethe to Hölderlin to Nietzsche to Heidegger. It is a resonant echo from Pindar between Hölderlin and Nietzsche, coming to be what one is, at the end of an unlikely and longer day as a coming home that can only be mediated as remembrance, as and through what is forcign, because as Heidegger draws out these reflections, what is most one's own remains what is most alien in exactly the passage he named Ereignis.

\footnotetext{
C. May, Reinhard: Lx oriente lux. Heideggers Werk unter ostasiatischen Einfluß. Stuttgart 1989. And: Parkes, Graham (ed.): Nietzsche and Asian Thought. Chicago 1991.

is So utterly other that one author ultimately remarks "there were no Greeks in the first place and therefore no (Orient or Hesperia (or Germany) in the first (or last) place either." Warminski, Andrej: Mounstrous History. Heidegger Reading Hölderlin. In: Fioretos, Aris (ed.): The Solid Letter. Readings of Hölderlin. Stanford 1999, p. 214 . A related concern with racism is adumbrated with reference, of all things, to the "brown" women of the Garonne - one imagines a similar darkness should be ascribed to Nietzsche's own "kleines süsses Weib von Niedertracht und Anmuth" (I:H, Warum ich so klug bin 7, KS A 6, p. 290) evoked precisely in the context of the poem that we have traced to Hölderlin and as the kind of woman who reminds him of the music of the south, and the name of Venice.
} 
Articulating the relation between thinkers such as Nietzsche and Heidegger, we can take Hölderlin to mean that the disposition over one's own is unfree and hence we are to turn to what is foreign. But according to Nietzsche, and precisely for the Germans themselves in their aspiration for the "best" that has ever been, for things imagined Greek, "sind alle Brücken abgebrochen" (KSA $11,41[4])$ and the lack of national innocence must be underlined, for the same shattered prospect holds for the French, as for the English, certainly for Americans, for Slavs, for Africans, for all peoples in the new fiercely nationalistic world-order.

The communicative key might lie in the almost that must be counted in the place of so much in life. It is only afterwards that the poet is able to begin to say to us, stunned as we are, that Schmerzlos sind wir und haben fast/Die Sprache in der Fremde verloren (Mnemosyne, 2. Fassung) - and only afterwards that we can begin to return to or read a sense back into Hölderlin's imperative claim "Deßwegen sind die Griechen des Heiligen Pathos weniger Meister, weil es ihnen angeboren war." In place of the holy pathos, instead of their own very Greek, very oriental fire, they dispose magisterially over "Junonische Nüchternheit" exactly in the measure to which they made it their own. ${ }^{59}$ To recognize the only possible transit in what Nietzsche called "die Regenbogen der Begriffe" (KSA 11, 41[4]) between foreign lands of thought, ${ }^{(6)}$ one must recognise not the passion for thinking he teasingly mocks as the will to "Geisterhaftigkeit" - naming scholars "gräcisirende Gespenster" - but rather one must anticipate the place of bodily bearing or the corporeal necessity that holds the key to divine happiness: one must come to oneself, not as a homecoming but a re-cognition of the foreign that inheres in one's own heart and history.

Nietzsche begins one of his most important Prefaces with the claim that we are strangers to ourselves, to conclude with the exigence of learning to read (as he elsewhere reminds us of the necessity to learn how to think and to learn how to love) (11 $^{1}$ and Hölderlin explains "Aber das Eigene muß so gut gelernt seyn, wie das Fremde. Deßwegen sind uns die Griechen unentbehrlich. Nur werden wir gerade in unserm Eigenen, Nationellen nicht nachkommen, weil ... der freie Gebrauch des Eigenen das schwerste ist." ${ }_{62}$ Nietzsche's effort to approximate the problem of "der freie Gebrauch des Eigenen" lies in his work, patently traced through the lines of the self-reflected lineage of an author's self-

\footnotetext{
59) Hölderlin: Letter to Böhlendorff, 4 De\%. 1801. St $\$ 4, p. 426.

(1) As Niet\%sche's Zarathustra asks of words and tones: "sind nicht Worte und Töne Regenbogen und Scheinbrücken zwischen Ewig-Geschiedenem?" And then "W"ie licblich ist alles Reden und alle Lüge der 'Töne! Mit 'Tönen tanæt unsre Liebe auf bunten Regenbögen" ( $/$ a III, Der (jenesende $2, \mathrm{KS} A 4$, p. 272).

6 GM, Vorrede 1.

62 Hölderlin: Letter to Böhlendorf. St $\Lambda$ 6, p. 426.
} 
becoming in terms of his affects and effects, that is, his Ecce homo. Wie man wird was man ist. ${ }^{6.3}$

The prejudice contra Germany (and its historical equation with Nazism) and antiquity (called Greece) is the same as the "prejudice" or "convicted" thinking of the nineteenth-century academic response to Hölderlin which had judged him, as he had been in Nietzsche's then-contemporary response to this judgment, qua all-too-Greek, and hence: qua insufficiently German, far too strange and - this is the Cartesian bugbear of both poetry and philosophy - insufficiently "clear." This is the prejudice the seventeen year-old faced in the wake of his advocacy of his "Lieblingsdichter," justifying his personal enthusiasm for Hölderlin. His instructor's critical comments were exactly devastating, repeating the same judgment Nietzsche's essay had challenged and recommending that Nietzsche save his advocacy for a healthier, clearer, more "German" poet. ${ }^{64}$ Nietzsche's response to this critique was delayed until the oblique criticism of Vischer, ultimately with a convergent reference to the very point of Hölderlin's own letter to Böhlendorff between what is one's own and what is foreign, the difference between what is achieved with ease or grace and what can only be won in a rain of fire, kissed by language, as Bettina von Arnim's enthusiasm expressed Hölderlin's vocation as a poet, as the very elemental fire of antiquity. Bathed in fire, standing poet's head drenched in aitherial lightening, wins for the Greek (this is the tension tensed within itself, the one in itself differentiated, that is the Vermaechtnis contrasting the oriental[a-orgic, nature] with the Western European [org-anic]), what is its own nature in the play or fire of the word. Nietzsche discovers the same tension in the very different, still affine names of the gods Dionysus/Apollo and the poets Archilochus/Homer in the oppositional dynamic of the Die Geburt der Tragödie. ${ }^{65}$

Beyond Nietzsche, Heidegger finds the most dissonant terms to convey the legacy of ancient Greece and its poets, which he explicitly appropriates from Hölderlin in his reading of the strange and the uncanny [Unheimliche] in Hölderlin's translation of Sophocles' Antigone. And thus, if only for this reason, the

(13 Heidegger's word is expressed in Being and Time as self-appropriation, whereby what Dasein recovers for the sake of authentic being itself is its own past for the sake of its own possibility. Heidegger's best Hölderlinian expression of the need for such a retrieve is his claim "Das ontisch Nächste und Bekannte ist das ontologische Fernste, unerkannte, und in seiner ontologischen Bedeutung ständig Übersehene." Heidegger, Martin: Sein und \%eit. Tübingen 1984. \9, p. 43 .

".t "Ich muß dem Verf. doch den freundlichen Rath ertheilen, sich an einen gesundern, klareren, deutscheren Dichter zu halten." (BAIW 2, Nachbericht, p. 430) According to Curt Paul Janz, the author of these lines was most likely to have been Karl August Koberstein. See: Janz: Friedrich Nietzsche. Biographie. Bd. I. München 1978, p. 80.

6.5 Hence Nietzsche even uses this language for Hölderlin's Hyperion, "diese Prosa ist Musik" (BAW" 2, p. 3) contra the "Junonische Nüchternheit" that is supposedly the purest nature of, and so unapproachably nearest nature of, the Germans. 
recent tactic of re-reading the postmodern conception of (Levinasian/Derridaean) difference or alterity against Heidegger's concern for the foreign and the distant cannot be expected to work against the one whose most enduring achievement was to teach a generation of scholars that "man kann vielleicht das Denken lernen" - in Arendt's very solemnly Junonian encomium. That Heidegger was a teacher would fit him, in his own language, into the place of those who are just what they are, as Nietzsche claimed and as Hölderlin was only a poet: "Dichter nur, aber dann wirklich Dichter," 66 just as one may speak of "priests only" and "rulers only," - but then actual, or real [wirklich] priests and rulers, as Heidegger characterizes this exigence sometimes called authenticity in his reading of the first stasimon of Sophocles' Antigone in Einfübrung in die Metaphysik. Heidegger's exactly magisterial - as Lehrer not Führer - rule was witnessed not only by Arendt but Gadamer and Löwith (one of those who would move from student to antagonist during and after the war). In Arendt's expression, "Das Gerücht sagt es ganz einfach: Das Denken ist wieder lebendig geworden, die totgeglaubten Bildungsschätze der Vergangenheit werden zum Sprechen gebracht, wobei sich herausstellt, das sie ganz andere Dinge vorbringen, als man mißtrauisch vermutet hat." ${ }^{67}$ But this means that Heidegger's language-referred effort to trace the relationship between Germany and Greece has more in common with Nietzsche's tragic sensibility contra the standard review of the reception of antiquity than has previously been conceded - given the antagonism scholars continue to install between Heidegger and Nietzsche, as an ostracising chasm eliminating the one philosopher who engages Nietzsche for philosophy (and not merely for and as an exegesis of his thought). For Heidegger, for Nietzsche, and for Hölderlin, the Greek is not imagined proximately German (the banality of saying the same) so much as utterly distant from the German. Hence, and much rather, the modern is charged to come to win itself by an effort to approach the foreign, to track, and so to measure antiquity with the sense of a prior eclipse or disappointment in Heidegger and echoing in Hölderlin's double and complex sense of the elusive challenge of archaic measure, nie treff ich, wie ich wünsche,/Das Maas.... ${ }^{68}$ Hence Lacoue-Iabarthe reminds us of this just double-reflex, although he takes himself to be saying something utterly new, and not already echoed by Nietzsche, and not already to be found in Heidegger's response to Hölderlin. ${ }^{69}$ This is "Oriental Greece, if you will, always

6r. Heidegger, Martin: Finführung in die Metaphysik. Tübingen 1966, p. 117.

6. Arendt, Hannah: Martin Heidegger ist achtzig Jahre alt. In: Neske, Günter/Kettering, Emil (eds.): Antwort. Martin Heidegger im Gespräch. Pfullingen 1988, pp. $233-254$, p. 235.

68 Hölderlin: Der Einzige. It should not be thought that this measure is calculative, be it calculative thinking or some other logical stricture but commentators have made this claim exactly concerning Heidegger, so compelling what should be a manifest qualification.

(1) See: Lacoue-Labarthe, Philippe: Typography. Mimesis Philosophy Politics. Cambridge, Massachusetts 1989, for this double reflex, which Lacoue-Labarthe, with Reiner Schürmann, names a double bind and traces to Gregory Bateson in Schürmann, Reiner: $\Lambda$ Brutal Awakening to 
tempted in the direction of what Hölderlin calls the aorgic in order to distinguish it from the organic. ... is finally what continues to haunt the German imaginary up to our time, and what will at any rate traverse the whole of the text of philosophy from Hegel to Heidegger."70) And with this, with "the Greece Hölderlin invents" to use Lacoue-Labarthe's expression, we return to Nietzsche and the tragic mode of antiquity. ${ }^{71}$

In this tragic mode, the name of Heraclitus corresponds to the place of Iimpedocles in Nietzsche's text. Indeed, Nietzsche explicitly ranges "Die alten Philosophen, die Eleaten Heraklit Empedokles als die tragischen Philosophen" (KSA 7, 5[94]). Such a comparison can seem tendentious because Nietzsche's description of the "moralische" comprehension of Empedocles" "Thier und Pflanzenwelt" is typically expressed in terms of a simply Schopenhauerian impulse: “,Wille“ universal," referring back to Empedocles' expression of "der universale Geschlechtstrieb und Haß” (KSA 7, 19[134]). Paralleling Heraclitus with Empedocles, Nietzsche also highlights Heraclitus's basic misanthropy, in good philological exactitude, in careful contrast to Empedokles'/ Yarathustra's popular devotion to his people, towards the end of - or in a Hölderlinian modality - for the sake of a higher reconcilation with the world of nature and in a still greater context, with time or the divine. ${ }^{72}$ But, Nietzsche's circumspect context must be considered with reference to this same coordination between Empedocles, the most esoteric of the presocratic philosophers, and hence the least comprehended and comprehensible, and the figure of Heraclitus himself, which association the young Nietzsche effects with reference to no one but Anaximander. ${ }^{73}$ Hence Nietzsche writes, "Bändigung des Wissens-

the Tragic Condition of Being. In: Harries, Karsten/Jamme, Christoph (eds.): On Heidegger's Beiträge zur Philosophie. Kathleen Blamey (trans.). New York 1994, and which I call a reflex because it catches the more dynamic structure of the German relation to Greece.

"L Lacoue-Labarthe: Typography, op. cit., p. 244.

-1 Tilman Borsche's discussion of Nietzsche's "Erfindung der Vorsokratiker" (In: Simon, Josef (ed.): Nietzsche und die philosophische 'Tradition. Würzburg 1985, pp. 62-87) omits Empedocles. But it cannot be that he shares Veronique Fóti's over-credulous conviction that Nietzsche is "strangely reticent" with regard to Empedocles in her: Empedocles and Tragic Thought: Heidegger, Hölderlin, Nietzsche. In: Jacobs, David C. (ed.): The Presocratics and Heidegger. Albany 1999 , pp. $277-294$, p. 277 , which claim Fóti cannot have concluded on the basis of a direct encounter with Nietzsche's work, but an abstraction - disregarding context - of Gadamer's discussion of Nietzsche's Philosopby in the Tragic. Age of Greece. It should be noted that Nietzsche seems to encourage similarly cavalier claims in many otherwise patient scholars.

-2 But in this context note further Nietzsche's early comment: "Die Poesie wird Politik, Rede. Das Reich der Prosa beginnt. Früher selbst in der Prosa die Poesie. Heraclit, die Pythia. Democrit. Empedocles." (Nachlaß 1869, KSA 7, 1|7|)

- Nietzsche makes the larger assertion regarding all ancient philosophers: "Jeder von ihnen war cin streitbarer gewaltthätiger Ty rann." (MA I, 261; KSA 2, p. 215) And he refers to this same tyrannical drive to rule in his discussion of a related (or identical) drive to establish specific philosophical cults or sects in FW 149. 
triebes - oder Stärkung des Mythisch-Mystischen, des Künstlerischen, (Heraklit Empedokles Anaximander.) Gesetzgebung der Größe." (KSA 7, 23[14]) ${ }^{74}$ Heraclitus, Empedocles, Anaximander are presented as ruler-sages. Listing "Empedocles Liebe und Haß in Griechenland" with "Heraclit. Cosmodicee der Kunst" and adding, "Democrit und Pythagoreer. Naturwissenschaft und Metaphysik" (KSA 7, 21[15]), Nietzsche regards both Heraclitus and Empedocles not merely as lawgivers but exactly as artists of the mystical, mythical (and, Nietzsche affirms, in Empedocles' case: of the magical).

Nietzsche associates Heraclitus and Empedocles within his own apostrophic but philologically dictated history of ancient thinkers. ${ }^{75}$ In his notes or studies, from early to late, Nietzsche rarely singles any one name out of context (and this is a significant difference again to the published declarations where he, like Hegel, frequently proclaims his affinity with Heraclitus above all). ${ }^{76}$ Nietzsche traces the names of antiquity as they are given to us, in citation and report, in terms of influence, a dedication which took every bit of Nietzsche's philological formation and which he pursued not to abandon philology for philosophy, as some authors imagine, but exactly in order to raise critical questions in that same tradition.

74 See further: JGB 204, KSA 1, p. 603; KSA 7, 5[94], 23[14]; KSA 11, 34[73], etc.

75 The fact that Nietzsche came to philosophy not by training but pure vocation, is a circumstantial detail the contravention of which, Hugh Lloyd-fones lightheartedly but insightfully remarks, inclines "some of his interpreters to write as if Nietzsche had only drifted into classical philology by mistake." Lloyd-Jones, Hugh: Nietzsche and the Study of the Ancient World. In: O'Flaherty, James C. et al. (eds.): Studies in Nietzsche and the Classical Tradition. Chapel Hill 1976, pp. 1-15 (p. 3). But Karl Reinhardt assesses the common judyment of his profession when he observes drily that "The history of philology has no place for Nietzsche, his positive achievements are too few for that..." Reinhardt, Karl: Vermächtnis der Antike. Göttingen 1960. If A. W. Pickard Cambridge's: Dithyramb Tragedy and Comedy: Oxford 1927; 1997, made no reference to Nietzsche, this omission is finally made good with a plausible and almost postmodern parsing in Porter, James I.: The Invention of Dionysus. An Essay on the Birth of Tragedy. Stanford 2000. And Henrichs, Kerenyi, Burkert, offer greater and lesser exceptions to the conservativism of the postmodern view Porter illuminates in his study: See also: Grant, George P.: Nietzsche and the Ancients. Philosophy and Scholarship. In: Dionysos 3 (1979), pp. 5-16. Pöschl, Viktor: Nietzsche und die klassische Philologie. In: Flashar, H. / Gründer, K. / Horstmann, A. (eds.): Philologie und Hermeneutik im 19. Jahrhundert. Göttingen 1979, pp. 141- 155. Borsche, Tilman / Gerratana, Federico / Venturelli, Aldo (eds.): 'Centauren-Geburten'. Wissenschaft, Kunst, und Philosophie beim jungen Nietzsche. Berlin 1998. Conway, Daniel / Rehn, Rudolf (eds.): Nietzsche und die Antique Philosophie. Trier 1992.

76 This repeated and explicit association is not dissimilar to Hegel's claim, which has not only impressed Nietzsche, that his book on logic included every sentence from Heraclitus, by design. The background of this claim was patent enough that a Viennese admirer, Siegfried Lipiner, could write to him about it (()kt. 15, 1877). Cf. Nietzsche's own indirect comparison of Hegel and Aristrotle in an epistemological context including Heraclitus: "es entscheidet nicht der reine Lirkenntnifitriel, sondern der aesthetische: die wenig erwiesene Philosophie des Heraklit hat einen größeren Kunstwerth als alle Sätze des Aristoteles." (Nachlaß 1872-73, KSA 7, 19[76]) 
Nietzsche articulates such parallels within the scheme of art without claiming a literally historical affinity. Paired in this fashion to Empedocles, Heraclitus can be matched with the "uranfänglich[e]" definition of "die bildende Kraft des Künstlers” (KSA 7, 19[134]). In this association, Nietzsche's philological practice, just as his critics have charged since Ulrich von Wilamowitz-Möllendorff, seems as little tied to historical references as the many other historical and thencontemporary nominal references characterising the style and substance of his discourse - a point which illustrates less his imprecision than it should be read as an object demonstration of the critical insight of his philology in the very context of scholarship as such. Any other practice would illustrate what Nictzsche named a lack of philology (JGB 47; cf. AC 52; KSA 13, 15[82]): thus Nietzsche's energetic and apparent imprecision contests the scholastic convictions proper to philology as much as to philosophy, withal, contra the ideal of science in general. This critical contention against the convicted security of received knowledge, challenging the supposed facts of the same, is the essence of Nietzsche's critical epistemology - the same epistemology that Nietzsche scholarship, be it German or American or French (not to mention mainstream philosophy), continues to ignore by regarding Nietzsche as no more than a moral or even a political philosopher. ${ }^{77}$ For, in context, in his own reading of antiquity and its unique art of tragedy, Nietzsche employs the names of Empedocles and Heraclitus for their insight into nature itself, opposing reigning convention ("Dieser Schein der 'griechischen Heiterkeit" in Sokerates und die griechische Tragoedie) and to put the point on his own counterreflection:

als ob es nie ein sechstes Jahrhundert mit seiner Geburt der Tragoedie, seinen Mysterien, seinen Empedocles und Heraclit gegeben habe, ja als ob die Kunstwerke der grossen Zeit gar nicht vorhanden seien, die doch - jedes für sich - aus dem Boden einer solchen greisenhaften und sklavenmässigen Daseinslust und Heiterkeit gar nicht zu erklären sind und auf eine völlig andere Weltbetrachtung als ihren Existenzgrund hinweisen. (KSA 1, p. 606)

Nietzsche's artistic account of the nature of understanding (i. e., the Nietzschean illusion of knowledge) thus exemplifies his very apostrophic and specifically antagonistic or polemical history of philosophy, e. g.: "von Thales bis Sokrates - lauter Übertragungen des Menschen auf die Natur - ungeheure Schattenspiele des Menschen auf der Natur, wie auf Gebirgen!" (KSA 7, 19[134])

-. Therebr; of course, we handily gain the right both to appropriate his ideas and to chastise him on these same terms: see Robert Pippin in this volume. But see also the author's own efforts to read Nietzsche in the context of his philosophy of science and critique of truth. Babich, Babette L.: Nietzsche's Philosophy of Science. Reflecting Science on the Ground of Art and Life. Albany 1994. Babich, Babette I:. in cooperation with Cohen, Robert S. (eds.): Nietzsche and the Sciences [Boston Studies in the Philosophy of Science.] 2 vol. Dordrecht 1999. 
Beyond Nietzsche's associative reading of and between the names of Heraclitus and Empedocles, scholars from Wilhelm Dilthey to Eduard Gaède, Jürgen Söring, Vivetta Vivarelli, and recently, David B. Allison, have explored the connection between Nietzsche's Zarathustra and Hölderlin's Empedokles. ${ }^{78}$ Beyond overt connections, Nietzsche's Zarathustra, including his versions or drafts for the same in his notes, echoes both the character and the function of Hölderlin's Empedokles, not only with reference to the historical philosopher but as a creative, literary and dramatic venture or "work." In this way, Nietzsche's centurion's query in his Unzeitgemässe Betrachtungen, reflecting upon Schopenhauer's pessimism, “,bejahst denn du im tiefsten Herzen dieses Dasein? Genügt es dir? Willst du sein Fürsprecher, sein Erlöser sein? Denn nur ein einziges wahrhaftiges Ja! aus deinem Munde - und das so schwer verklagte Leben soll frei sein" ", ${ }^{79}$ claims the sacrificial moment beyond this life enacted by "Empedokles" as a spiritual answer and offers the key to Nietzsche's reflections not only on the ideal of a timely death but also concerning the stylistic question of endings. Likewise, Nietzsche describes the tragic countenance and comportment of Anaximander as Empedokles' own exemplar: "Er lebte, wie er schrieb; er sprach so feierlich als er sich kleidete, er erhob die Hand und setzte den Fuß, als ob dieses Dasein eine Tragödie sei, in der er, als Held, mitzuspielen geboren sei. In alle dem war er das große Vorbild des Empedokles" (PHG 4, KSA 1, p. $820 \mathrm{f}$.) - a description of Zarathustra's Empedoclean mien and manner that similarly embraces Zarathustra in the idealized light of his own inventor: "Empedocles ist der reine tragische Mensch. Sein Sprung in den Aetna aus - Wissenstrieb! Er sehnte sich nach Kunst und fand nur das Wissen. Das Wissen aber macht Fausten." (KSA 7, 5[94]) Later, Nietzsche adds to this tragic projection of the transformation of art as he conceives it throughout his philosophy and in his own Zarathustra project beyond the limits of the symbolic and sacrificial death of Empedokles. In addition to the project of the ascetic ideal in science "Das Wissen ohne Maß und Grenze," in a manner reminiscent of his later incantation of the life-affirming urgency of art as a shield in the face of the erzeugen, als die Heilerin." (KSA 7, 7[101]) A similarly aesthetic reference is evident in Nietzsche's own careful association of Empedocles as rhetorician and the speeches and the task ascribed to Zarathustra. ${ }^{80}$

\footnotetext{
${ }^{78}$ In addition to Dilthey, Wilhelm: Das Erlebnis und die Dichtung. 16. Aufl. Göttingen 1985; and Allison, David B.: Re-Reading the New Nietzsche. Lanham, Maryland 200(); see Vivarelli, ViGrèce. Paris 1985, pp. 33-4().
. Indouard: Figures d'Eimpédocle. In: Nietzsche, Hölderlin, et la

7) UB III, Schopenhauer als Iitich books, Nietzsche further lirzieher 3, KSA 1, p. 36.3. Iater, in his five prefaces to five unwritten lin. Cf. KSA 1, p. 755.

se Cf. KSA 7, 16[17]; 23[22]; 26[1]; 32[14], etc.
} 


\section{The Nature of the Tragic as Suffering in Niet:ssche and Hölderlinian Joy}

Expressed as the tragic work of art, Nietzsche understands the archaic nature of tragedy not only as a poetic or musical conception but recollected on the terms of suffering: "Die Welt vom Leiden a us zu verstehen ist das Tragische in der Tragödie" (KSA 8, 6[20]). Nietzsche's response is the avocation of love. Calling something good, in blessing and gratitude for its being as such, is the truth of tragedy and this truth becomes the love of life Nietzsche names amor fati, affirmation. Nietzsche's Zarathustra thus recalls Hölderlin's highest tonalities, as they are expressed in the extraordinary final words of the novel Hyperion: "l.ebendige Töne sind wir, stimmen zusammen in deinem Wohllaut, Natur! wer reißt denn? Wer mag die Liebenden scheiden?" 81

Recollecting the resonance of this same conflicted reconciliation, the quarrel between Zarathustra and life in Das andere Tanzlied is posed in shining tones recalling Hölderlin's influence on Nietzsche as we have heard its echoes from the beginning, now expressed as what one reader has named Nietzsche's barcarole, in a Pindarian echo that is Nietzsche's own:

"In dein Auge schaute ich jüngst, oh Leben: Gold sah ich in deinem Nacht-Auge blinken, - mein Herz stand still vor dieser Wollust:

- einen goldenen Kahn sah ich blinken auf nächtigen Gewässern, einen sinkenden, trinkenden, wieder winkenden goldenen Schaukel-Kahn!

(Za III, Das andere Tanzlied 1, KSA 4, p. 282)

In the back and forth cycle of attraction and repulsion to follow, Nietzsche, promising the eternal as the shuddering resonance, or standing wave of the selfsame, echoes the Heraclitean, Empedoclean mode heard in the conflicts of lovers and the reconciliation of all change in the height of nature, once again, at the end of Hölderlin's Hyperion: "Wie der Zwist der Liebenden, sind die Dissonanzen der Welt. Versöhnung ist mitten im Streit und alles Getrennte findet sich wieder." 82

Tragic suffering speaks the essence of joy not, as Hölderlin reminds us with sustained amazement, "das freudigste freudig zu sagen." 83 Yet to discover joy spoken by sorrow is not to suppose that there is "no" suffering - or that suffering is an illusion. Hölderlin's sensitivity to pain exactly in (not even in) joy gleams in every word that speaks of mild air, soft breezes, the tension between abundance and loss: Drum bleibe diß. Ein Solin der Lirde/Schein ich; zu lieben gemacht,

$\$ 1$ Hölderlin: Hyperion, St $\ 3$, p. 160 .

$\$ 2$ Ibid.

8.3 'This is the black pearl of Hölderlin's Sophocles: I zele versuchten umsonst das Irendigste freudig z" sagen / Hier spricht endlich es mir, hier in der Trauer sich aus. 
$z u$ leiden, ${ }^{84}$ and it is love again that threatens its absence in the second part of Ilälfte des I eebens:

...n'o nehm' ich, wenn

Es Winter ist, die Blumen, und n'o

Den Sonnenschein

Und Sibatten der Eirde. ${ }^{85}$

What is manifest in Hölderlin's pure tension, in his reflex of life, is transfigured into a sustained emphasis on pain in Nietzsche's tragic reflections on life and the ultimate ideal of affirmation that is the core of Nietzsche's thinking on will to power as the eternal return of the same as amor fati. ${ }^{86}$

Thus it is possible to hear a (necessarily) transfiguring ambiguity in Nietzsche's cheapest, harshest claims exactly addressed to the nature of pain and empathy. As offensively as he emphasises "Eine schmerzhafte Nacht eines einzigen hysterischen Bildungs-Weibchens" (GM II 7, KSA 5, p. 303), Nietzsche also compares the suffering of savages and the sufferings of animals in the vivisection and the thoughtless cruelty as practiced to this day in university and industrial research contexts, exactly beyond the fearsome constellation of such a community of suffering. For this reason, the deliberately provocative point of his collocation of comparisons (opposing scientific perspectives on such things as continue to plague philosophical reflection as pain itself) is easily overlooked in our politically enlightened horror or "better-knowing" contemplation and correlevant urge to overspring its content:

Vielleicht that damals - den Zärtlingen zum Trost gesagt - der Schmerz noch nicht so weh wie heute; wenigstens wird ein Arzt so schliessen dürfen, der Neger (diese als Repräsentanten des vorgeschichtlichen Menschen genommen - ) bei schweren inneren Entzündungsfällen behandelt hat, welche auch den bestorganisirten Europäer fast zur Verzweiflung bringen; - bei Negern thun sie dies nicht. (Die Curve der menschlichen Schmerzfähigkeit scheint in der That ausserordentlich und fast plötzlich zu sinken, sobald man erst die oberen Zehn-Tausend oder Zehn-Millionen der Übercultur hinter sich hat; und ich für meine Person zweifle nicht, dass, gegen Eine schmerzhafte Nacht eines einzigen hysterischen Bildungs-Weibchens gehalten, die Leiden aller Thiere insgesammt, welche bis jetzt zum Zweck wissenschaftlicher Antworten mit dem Messer befragt worden sind, einfach nicht in Betracht kommen.) (GM II 7, KSA 5, p. 303)

Beyond the polemical (i. e., contra the patently scientistic judgment of nineteenth-century medical science), the point of Nietzsche's detailed description of pain highlights the elusiveness of sensibility, the impossibility of sentiment. We

\footnotetext{
84 Hölderlin: Die Heimat, St $\lambda$ 2, p. 19.

sí Ibid., p. 117.

s. GT 3; 7; 10; 22; and in general the comment from the notes precising Soplokkles der Dicbter der Ixiden des agonalen Individumms.
} 
do not and can never feel another's pain. Indeed, we can feel it so little that we never imagine or concede extraordinary respect for another's pain - which awe or respect might be the appropriate complement to ignorance, but much, much rather, in a move Nietzsche analyses in a number of similar cases and exactly where the moral rule does command the highest respect for the other, we diminish the other's pain in any estimation we might form of it in our own minds: we imagine that what we feel, the other feels likewise. For this reason and with a perfectly good conscience, we degrade the "perceived" or presumed pain of another to greater or lesser degrees of insubstantiality. Where we feel nothing, (it seems!) nothing exists: "Wofür wir keine Sinne haben, <das > existirt für uns nicht" (KSA 9, 11[75]). ${ }^{87}$ Thus - and not only in general - one determines that certain human beings simply feel less pain, just as animals are, per definitionem, said to "feel" nothing scientists call pain but rather "stimuli responses," just as medical theorists once proposed similarly to reduce the differences between social and cultural differences in the expression of pain and in perception in general between the races, Black, White, Asian, and which races once also included the fantasy of difference between the "Aryan" and the Jew.

Owing to Nietzsche's very Greek sensibility, developed in response to Pindar and Sophocles and as evidenced by his affinity for Hölderlin, the problem of tragedy (blindness, stupidity, cursedness, injustice, extra-human pain and ordinary sorrow) as music, as art, as life was to remain Nietzsche's problem as a problem. This is his key question which he develops from his book on tragedy to his last reflection on idols, Wagner, and the Antichrist. Nietzsche's insight into the essence of tragedy holds the heart of cruelty as the draught of tragedy, which he reprises as the meaning of tragic wisdom or amor fati thought together with the insight into life itself: "alles Werden und Wachsen, alles ZukunftVerbürgende bedingt den Schmerz ..." (GD, Was ich den Alten verdanke 4, KSA 6, p. 159) - as the very deliberate affirmation of subjective pain in every process and needful in every innocence. As Karl Reinhardt's uncompromising clarification of the still misleading characterisation of Nietzsche as "I elenensphilosoplo" reminds us: "Allerdings, was Nietzsche "Leben" nennt, ist ein sehr unbequemer, fordernder Begriff des Lebens." 88

Nietzsche's unsparing focus on pain diverges from Hölderlin's arch Empedoclean, consummately transfigured relation between love (I iebe) and suffering (leiden, I aid) and differs further from Heidegger's less passionate aspiration in the turns of what the first finds as the frendigste and the latter names Gelassenbeit.

\footnotetext{
Cf. Nietzsche's clarification: "Feiner zugesehn, heißt solches „das ist falsch" eigentlich nur ,ich fühle darin nichts von mir", ,ich mache mir nichts daraus” „ich begreife nicht, wie ihr nicht mit mir fühlen könnt" (KSA 12, 2[35])

s\$ Reinhardt: Vermächtnis der Antike, op. cit., p. 345.
} 
Nietzsche's struggle with the uncomfortable and demanding insight he names tragic knowledge not only drives his reading of antiquity - "über den Lessingschen Laokoon hinauszuschreiten" ${ }^{89}$ - but is the essence of Nietzsche's Dionysian "invention" or "discovery," here greeted as uncanny guest, as the dangerous festival prince. 90 The question of the nature of tragedy, the reconciliation of individual suffering (indifference) and the divine nature of the world, is the same question Hölderlin resolved (but, relevantly, did not finish) in brilliant poises in his Limpedokles. In this way, what Hölderlin calls the aorgic appears in Nietzsche's The Birth of Tragedy' in the same Sophoclean epigraph Hölderlin affixed to the second volume of Hyperion, ${ }^{11}$ spoken by Nietzsche's Silenus, illuminating the tenacity of foundational pessimism with Nictzsche's insight ${ }^{92}$ into the Dionysian world. ${ }^{93}$

Nietzsche's darkest vision of antiquity - which Nietzsche himself describes as an inverted highlight, like the blind spots of inverted darkness when one closes one's eyes after looking at too bright a light, or like the reflective achievement of the horrifying phantom who could stare into the shadows within, turning his own eyes inward at himself - constitutes the still point between Nietzsche and Hölderlin. ${ }^{94}$ We may find that following this line of thought inclines us to redraw our understanding of what we call Nietzsche's cruelty apart from the exactly French frisson of Bataille or Klossowski or, more recently, Sarah Kofman. This is the pessimistic insight Nietzsche shared with Hölderlin and it is the essence of tragic truth. We have seen this evident in his youthful epistolary paean which Nietzsche composed as much in his own defense as in Hölderlin's. ${ }^{95}$ And this was the project Nietzsche followed from the start.

As Nietzsche critically turned his review of the birth of an ancient art form from a forgotten sense of music to his advantage, in direct contrast with the classical tradition's conventional conviction on the matter (a convention that has

x" Nietzsche to Rohde, 7. ()kt. 1869), K( $3 B$ II 1, Nr. 33, p. 63.

"This troubling coincidence, as regarded from Nictzsche's perspective which is, indeed, how Heidegger regarded is not one current authors have emphasized in their advocacy of the Egyptian in Hölderlin. This last reading ranges from Peter Szondi to Wariminski to Robert Bernasconi and the realms of politically correct vision beyond these authors. The reading here notes that things are hardly this self-evident, as even a preliminary reference to Nictzsche's use of the term "Egyptianism" illustrates.

") Hölderlin: Hyperion, St $\Lambda$ 3, p. 92 . See Beißner's note, p. 469.

"2 Cf. earlier citations above concerning the relation between tone and music and the metaphors of light and color. Modern research finds a similar connection at the more superficial level of illusion or effect in virtual or digitalized images as well as acoustic representations (CDs).

9 ( 3 (3) 3.

"It Despite the necessary qualifications, this insight is not without influence and it could be said that today's philology only works in its wake. See for a more recent (and cautious) reference beyond the pathbreaking paradigmatic conventions of F. R. Dodds, Jane Harrison, Gerald Else, etc., beyond Lloyd-Jones: Nietzsche and the Study of the Ancient World, op. cit.

95 BAW I, October 1861, pp. 1-5. 
continued beyond Goethe and Winckelmann in the neo-Hegelian image of Greece as the childhood of mankind, veiled by the mists of primitive superstition), the tragic wisdom of the Greeks was a direct response to pain, as Nietzsche expressed this sensitivity. The Greeks, as one classicist sympathetic to Nietzsche, affirms, neither "sublimated" nor did they repress but instead "used for their purposes, terrible and irrational forces." "The difference between modern sophisticated readings of such extreme and irrational forces, qua sublimity and transcendence, is Nietzsche's claim that the Greek was superficial not because of a naïve, primitive, or childish blindness, but out of profundity. In consonance with, for the sake of, life: "dazu thut Noth, tapfer bei der Oberfläche, der Falte, der Haut stehen zu bleiben, den Schein anzubeten, an Formen, an Töne, an Worte, an den ganzen Olymp des Scheins zu glauben! Diese Griechen waren oberflächlich - aus Tiefe!"97

In this case, we see the lineaments of the image of nature or what Nietzsche also calls chaos to emphasize not its lack of order as much as its excess: nature, beyond the sublime, the Lacanian Real: uncountenanceable. ${ }^{98}$ The nature here described is the wild, untamed, and uncontrollable force (Hölderlin's divine, or aorgic, apeiron nature) opposed to the milder fantasy Nietzsche later (if not quite fairly) ascribes to the Stoics (JGB 9) or as may be gleaned from garden variety readings of Rousseau, or today's ecological pharasaicism.

Appealing to the surface of this excess in nature, Nietzsche's works themselves deploy the same extraordinary metaphors. To defend Hölderlin, the young Nietzsche recalled the colors of his poetry and Nietzsche himself is preoccupied with Hölderlinian gold from start to finish. Thus the same resplendence resounds in Menschliches, Allzumenschliches, characterizing the paintings of Claude Lorrain in substance "klingendem Golde" (MA II, Vermischte Meinungen und Sprüche 171) in the image of a transfigured nature. Why the color of gold? And we must ask, for although Nietzsche never forsakes the redemptive image of gold, we know that Nietzsche will later claim a compulsion to paint, as he

\% Iloyd-Jones, op. cit., p. 3.

()- FW, Vorrede 4; NI, Ipilog 2, KSA 6, p. 437. Nietzsche's great contribution to the understanding of antiquity is precisely this emphasis upon (Ricour's "suspicion" of) the seeming of seeming, the seeming of the surface. Thus (amid other loci) Zarathustra regards Oberfläblichkeit as a paradoxical virtuc ( $\angle \lambda$, Von den $A$ btrünnigen 2). But it should be noted that, in general, Nietzsche uses the term in a precisely perjorative sense (it is not for nothing that he uses the word when speaking of woman and, indecd, the French). (On a more elevated note, in his discussion of Vietziche and Schiller, Martin obscres that "Winckelmann and others may have known that there were hidden, irrational depths, but with the important exception of Hölderlin, these carlier Hellenists chose to suppress that knowledge, in order to stress / this is the ideal of Lessing's Laok:oon] the Greeks' untroubled harmony and serenity."

"98 For discussion of Lacan's uncanny register of the real and Nietzsche's conception of nature, see the author's: (On the Order of the Real. Nietzsche and Lacan. In: Pettigrew, David / Raffoul, François (eds.): Disseminating Lacan. Albany 1996, pp. 43-68. 
says, his happiness in other, wilder colors - echoed in other tonalities (cf. JGB 296), but still recalling the same play between color and tone we first saw in his student writings on the lambent song.

If we can suffer a penultimate excursus on art for the sake of this quotation of color and tone, it may be possible to contemplate the difference between the spaces of visual images in painting and the arts of sculpture and architecture, as the difference between dream and music, Apollo and Dionysus.

Apollo, as Nietzsche names him, "der "Scheinende"," is also "des Bildnergottes" (GT 1, KSA 1, p. 27 f.). But the "sunlike" eye of Apollo corresponds to an image of "jene maassvolle Begrenzung" - not the dissonant or reconciled attunement of music or tragedy or the working space of sculpture itself. When Nietzsche thus refers to Raphael's Transfiguration, he illuminates the play of illusion or appearance on the selfsame basis of "die schreckliche Weisheit des Silen" and revealing their "gegenseitige Nothwendigkeit" (GT 4, KSA 1, p. 39). But this is the same appearance that he will describe as hopelessly one-dimensional, aperspectival, so that in the aesthetic play of illusion "justifying" life and reality, we ourselves, caught in the play of life, have the same flattened consciousness "als es die auf Leinwand gemalten Krieger von der auf ihr dargestellten Schlacht haben" (GT 5, KSA 1, p. 47).

Where music is the Dionysian complement to the Apollonian vision of the drama, the consummate or complete work of tragic art requires the three-dimensional contours of sculpture or architecture, or even the four dimensions of theatre and dance. 'Thus the vision at the end of Die Geburt der Tragödie projects the transfigured music of philosophy as an attempt to think "eine Menschwerdung der Dissonanz," rather than the metaphorical phantasm of musical sweetness, as the very nature of human existence. In order to survive such "dissonance," in order to live, we need both Dionysus and Apollo. The image that Nietzsche gives for this vision is a thoroughly bodily one of space and sphere: it is the working of sculpture and architecture on one's being, the musical reflection of life in the Greece Nietzsche now "invents" for us:

im Wandeln unter hohen ionischen Säulengängen, aufwärtsblickend zu einem Horizont, der durch reine und edle Linien abgeschnitten ist, neben sich Wiederspiegelungen seiner verklärten Gestalt in leuchtendem Marmor, rings um sich feierlich schreitende oder zart bewegte Menschen, mit harmonisch tönenden Lauten und rhythmischer Gebärdensprache (G'T 25).

Although both deities, as interdependent, exact an equal claim on us, we can continue the contrast here as one between sculpture (not as Apollo's art but as architecture, as music in space) and painting (not as Dionysian color, but as an Apollinian vision). Hence, for a painterly example taken nearly at random, it might be claimed, given that Nietzsche knew nothing of Turner, that Nietzsche might not have been able to see the spin of nature through the artist's Turner's 
eyes, reflecting the industrial reconstitution of the colors and textures of the world Heidegger later condemned as the cybernetic world of modern technology, in Turner's paintings of the effluent transmutation of the frames of light and air traced upon the Western sky, now a century old and almost cloyingly romanticized as fatuously diaphanous visions of still English, still pre-industrial romance. But, to risk a parallel contrast, I submit, Nietzsche might have been able to see the work of time in space in Boccioni, in Brancusi, in Giacometti, not because these are somehow better or more modern artists but because these names name sculptors not only of objects (like Rodin) but space.

Plastic art, the art of sculpture, yokes space and time because (and from an exactly antique or Greek perspective) sculpture's resistance to the distance of contemplation distinguishes it from the prototypical art of painting, the same resistance allying it to architecture and music. One may not simply gaze upon, contemplate, or merely see a sculpture. Instead, seeing oneself in seeing (being seen as much as seeing), the statue's plasticity claims one, installing the visitor as a guest on its own terms, in response to it, within in its own space and hence caught into, captured by its own orbit. This is the reason the Laokoon, seen in person, face on - as it was first seen: indeed and out of doors - could exercise such a galvanic effect. ${ }^{99}$ It exerted a literally dimensional claim on those who encountered it, or described it for others in these ecstatic terms. This is the reason Hölderlin could have reacted (as apocrypha suggests he did) to a primal encounter with the sight of classical (however derivative, decadent, we would say: inauthentic) statues passing through the gardens of a private villa in France. The statue, especially under heaven, like Rilke's broken and demanding torso, utters an irrestible imperative, urging the change that an entire society was not then and still cannot master. One is as much seen by as one sees. One is claimed, transported by the statue itself, into the dimensional round of the sculpture's tension. Thus the contemporary viewer can also be poised, if only, for our technologized sensibilities, in a dim recollection of the way in which the Hellene would have had no choice but to be set against, arched in opposition to the measure of the statue (cf. KSA 1, p. 581 and KSA 11, 25[101]). Thus Nietzsche's early remarks refer not only to the "Statue als Verzauberung einer Seele in Stein" (KSA 8, 22[36]) but to "Verbergen der Tragödie (wie die Statuenwelt)" (KSA 7, 7[15]; cf. KSA 9, 7[101]), and he quotes Hölderlin not with all his rigor but to mark the damnation of the effort to capture the same esteem and the same response or sensibility in our flattened, tearing and not ripening, time. And in his early notes, Nietzsche cites Hölderlin himself, as crying: “,auch ich, mit allem guten Willen, tappe mit meinem Thun und Denken diesen einzigen

") Though, and to be sure, Pliny's description was itself so very influential that it could be claimed that it stood behind the institution of what has been named classicism. 
Menschen (den Griechen) in der Welt nur nach und bin in dem, was ich treibe und sage, oft nur um so ungeschickter und ungereimter, weil ich wie die Gänse mit platten Füssen im modernen Wasser stehe und unmächtig zum griechischen Himmel emporflügle."” (KSA 7, 29[107])

\section{Transfiguration and the Tragic Limit of Critique}

For Nietzsche, the history of modern culture since the Greeks (the only reference point he ever considers in the context of culture) has demonstrated that "Es hat sich unmöglich erwiesen, eine Kultur auf das Wissen zu bauen" (KSA 7, 19[105]) because the exclusive ideal of truth (and that divine exclusivity is the earmark of truth) kills: "Wahrheit tödtet - ja tödtet sich selbst (insofern sie erkennt, daß ihr Fundament der Irrthum ist)." (29[7]) For as Nietzsche describes it, the human longing for consummate truthfulness must be admired as $\mathrm{a}[\mathrm{n}]$ "herrliche heroische Lust des Menschen, in einer lügenhaften Natur! Aber nur sehr relativ möglich! Das ist tragisch. Das ist das tragische Problem Kants!" (19[104]; cf. [154]). ${ }^{100}$ Nietzsche articulates this heroic longing not only as a conflict between art and science but also in terms of the love philosophers, so-called lovers of wisdom, seem so much to lack (29|224]) exactly in their most acquisitive impulses. ${ }^{101}$ This "andre Wahrheitsgefühl stammt aus der Liebe, Beweis der Kraft. Das Aussprechen der beseligenden Wahrheit aus Liebe: bezieht sich auf Erkenntnisse des Einzelnen, die er nicht mittheilen muß, aber deren überquellende Beseligung ihn zwingt." (19[103]) Thus Nietzsche challenges the philosopher to aspire to the ideal of the lover, not the rigorous image of a scientist, in Kant's good sense, but instead, and exactly, the ideal of an artist of life.

101) Cf. GT 15. Such a longing for truth is grounded in an unknowing faith in knowledge, or illusion: "Die Logik, als Alleinherrscherin, führt zur Lüge: denn sie ist nicht die Alleinherrscherin." (Nachlaß 1872-73, KSA 7, 19|103]). Now, the early Nietzsche argues, as after an immense detour through the rationalist fantasy of Socratico-Aristotelian clarity; which is also to say Christianity, "So kommen wir, auf ungeheurem Umweg, wieder auf das natiirliche Verhalten (bei den Griechen) zurück." (Ibid., 19[105])

101 "Ach dieser Mangel an Liebe in diesen Philosophen, die immer nur an die Ausgewählten denken und nicht so viel Glauben zu ihrer Weisheit haben. Fs muss die Weisheit wie die Sonne für jedermann scheinen: und ein blasser Strahl selbst in die niedrigste Secle hinabtauchen können" (KSA 7, 29|224]; cf. Nictzsche's discussion of the sun in FI' 337. Vivarelli's reading offers a further reflection on this understanding of love as "verschwendeter Reichtum und Wollust am Untergang." For Nietzsche, one must further note the ironic relevance of the subtitle to . Also sprach Zaratbustra and his reflections on being understood throughout his work. For a discussion of one aspect of this irony and its subtle paradox precisely with reference to love see: Babich, Babette 1.: Nietzsche et Kros entre le gouffre de Charybde et l'écueil de Dieu. La valence érotique de l'art et l'artiste comme acteur - Juif - femme. In: Revue Internationale de Philosophic 54/211 (2000), pp. 15-55. 
The ideal of art, the ideal of the grand style, is the ideal of Bildung or realization. Not to escape or sublimate pain and suffering but: "über Schrecken und Mitleid hinaus, die ewige Lust des Werdens selbst zu sein, - jene Lust, die auch noch die Lust am Vernichten in sich schliesst." ${ }^{112}$ To realize the archaic ideal of tragedy is to embody the eternal joy of becoming: "jene Lust, die auch noch die I ust am Vernichten in sich schliesst" (EH, Die Geburt der Tragödie 3). By means of such an ideal Nietzsche can speak of art as a truth to life, regarding life as the reality opposed to and opposed by the ideal world of metaphysics as of logic, of religion and of science. ${ }^{10.3}$

This conception of life or reality as fearful necessity or chance, is taken in the pre-Socratic sense of the term, echoing not only in Aeschylus and Sophocles but in pre-Socratic philosophy from Anaximander to the quotations from Plato's Pythagorean Timatus. But for grandness of style, for greatness or nobility, Nietzsche keeps the same astonishing formula of love, which must be understood in conjunction with the reality of Lergehen and Vernichten, that is of course to say, in connection with time and life as its own passing or evanescence. Like Paul's description of love's infinite forbearance, "always ready to excuse, to hope, and to endure what comes" (I Cor. 13:7), like Shakespeare's better known gloss, lore is not love which alters when it alteration finds (Sonnet CXVI), Nietzsche affirms love's rigour: "dass man Nichts anders haben will, vorwärts nicht, rückwärts nicht, in alle Ewigkeit nicht. Das Nothwendige nicht bloss ertragen, noch weniger verhehlen - aller Idealismus ist Verlogenheit vor dem Nothwendigen sondern es lieben ..." (EH, Warum ich so klug bin 10). The "love" of life resonates in the equation Nietzsche sets "zwischen Thränen und Musik" (7) which he cannot dissolve. This same love is "jene göttliche Bosheit, ohne die ich mir das Vollkommne nicht zu denken vermag" (4). Exactly such an amor fati becomes the word he gives to his life in the story he tells himself at the Zarathustran moment of his life's decision. The consummation of love takes everything that will be and everything that has been all together. The affirmation of the eternal return is a selective benediction of everything, past, present, and future - transfiguring everything with the same golden or silver glance, like the glittering main of the evening sun, "voller Thränen und voll Lachens, ein Glück, welches [...] fortwährend aus seinem unerschöpflichen Reichthume wegschenkt und in's Meer schüttet" (FW 337), a vision of pure magnificence: the light of art. This gleaming vision denies nothing, changes nothing, resolves nothing: but transfigures and thus redeems everything, blessing everything with gold.

102 GD, Was ich den Nen verdanke 5; cf. H.H, Warum ich so klug bin 3.

113 Where "Dic Lüge des Ideals war bisher der Fluch über der Realität." (liH, Vorwort 2) 